See discussions, stats, and author profiles for this publication at: https://www.researchgate.net/publication/315697606

\title{
Stopped TTIP? Its potential impact on the world and the role of neglected FDI
}

Article in Economic Modelling · March 2018

DOI: 10.1016/j.econmod.2017.12.006

2 authors:

Maria C. Latorre

29) Complutense University of Madrid

37 PUBLICATIONS 222 CITATIONS

SEE PROFILE
Hidemichi Yonezawa

Statistisk sentralbyrå

28 PUBLICATIONS 199 CITATIONS

SEE PROFILE

Some of the authors of this publication are also working on these related projects:

Brexit View project

The Intergenerational Incidence of Green Tax Reform View project 


\section{MPRA \\ Munich Personal RePEc Archive}

\section{Stopped TTIP? Its potential impact on the world and the role of neglected FDI}

María C. Latorre and Hidemichi Yonezawa

Universidad Complutense de Madrid, ETH, Zurich

2017

Online at https://mpra.ub.uni-muenchen.de/77162/

MPRA Paper No. 77162, posted 1 March 2017 09:51 UTC 


\title{
Stopped TTIP? Its potential impact on the world and the role of neglected FDI
}

\author{
María C. Latorre (Universidad Complutense de Madrid) \\ Hidemichi Yonezawa (ETH Zurich)
}

\begin{abstract}
The Transatlantic Trade and Investment Partnership (TTIP) seems to be a doomed half-negotiated trade deal with Donald Trump in power. If it were definitely abandoned, the effects of what could have been the largest trade agreement in history would disappear. In this paper we analyze its potential impact on the world and on insiders and outsiders of the agreement using a Computable General Equilibrium (CGE) model. In our simulation, TTIP consists of reductions of tariffs, non-tariff barriers and a previously neglected component, namely, barriers to Foreign Direct Investment (FDI). The impact of the FDI component would be larger for the US than for the EU. In the US, it would contribute to nearly half of the overall impact of TTIP, while in the EU it would be nearly one third. Insiders would heavily benefit from TTIP but the effects could potentially be very slightly negative for outsiders (Middle East, Sub-Saharan Africa, Latin America, Southeast Asia and Other Advanced Countries), with the exception of the big Asian economies (China, Japan and India). The latter would remain unaffected. However, all the slightly potential negative effects would turn into positive with an "inclusive TTIP" (i.e., one avoiding third country discriminating rules and standards). An inclusive TTIP would benefit both insiders, who would gain more, and outsiders, who would be better off than without the TTIP. Welfare, GDP, wages, as well as aggregate imports and exports of the world economy would clearly increase following either a shallow or a deep TTIP agreement.
\end{abstract}

Keywords: Foreign Direct Investment, multinationals, trade agreements, Computable General Equilibrium, CGE, monopolistic competition.

JEL codes: C68, F14, F15, F17, F21

Acknowledgments: María C. Latorre gratefully acknowledges that this research has been conducted thanks to the financial support of Real Colegio Complutense at Harvard University and as a Research Fellow of both the Center for International Development (CID) at the Harvard Kennedy School and of Real Colegio Complutense. She also gratefully acknowledges the financial support from the Spanish Ministry of Economy and Competitiveness (Project: ECO2016-78422-R). The authors want to thank Edward Balistreri, David Tarr, Antonio G. Gómez-Plana and Rafael Myro for their very helpful comments and suggestions. In addition, they want to thank the comments of participants in seminars held in various institutions presenting different versions of this study: Marinos Tsigas (US International Trade Commission) and Raymond Mataloni (US Department of Commerce, Bureau of Economic Analysis). Of course, any errors are our own.

Corresponding author: María C. Latorre. Facultad de Estudios Estadísticos, Universidad Complutense de Madrid, Avda. Puerta de Hierro s/n, Ciudad Universitaria, 28040-Madrid. Tel. (34) 913943990 Fax: (34) 913944024 Email: mmunozla@ucm.es, ORCID ID: 0000-0001-8741-1897

Hidemichi Yonezawa ETH, Zurich 2 Zürich, Switzerland Tel. (41) 4463206 48, hyonezaw@ethz.ch 


\section{Introduction}

Among other protectionist measures, Trump has withdrawn the US from the Trans Pacific Partnership (TPP). The TPP looks dead, even though some of its members want to continue with the deal (Wall Street Journal, 2016). However, Trump has not made any explicit declaration about the Transatlantic Trade and Investment Partnership (TTIP). According to the latest news, the US administration will only negotiate bilateral instead of multilateral agreements. What does this mean for the TTIP? The head of the White House National Trade Council regards the TTIP as a multilateral deal and has claimed it is also dead, even though it seems Trump still has to confirm this (The Economist, 2017; Lester, 2017). On the other hand, individual member states do not have the competence to negotiate trade deals with another country, which lies with the European Commission. In that sense, the resulting agreement could not be a bilateral one. At the moment, TTIP negotiations are on hold and it will probably never happen.

The TTIP was the largest of what had been called the "modern trade agreements". The slow pace of the World Trade Organization (WTO) in attaining multiregional agreements had brought about a surge in regional and bilateral trade agreements since the beginning of the 1990s (Maggi, 2014; Baldwin, 2015). These regional negotiations had extended the scope beyond tariffs. This is understandable with the proliferation of Foreign Direct Investment (FDI) flows, trade in services, global value chains and other far-reaching elements related to trade. In fact, some scholars are suggesting that even the WTO should try to reach deeper trade agreements (Antràs and Staiger, 2012a, 2012b; Hufbauer and Cimino-Isaacs, 2015).

The potential impact of the TTIP had attracted great attention. It had raised vociferous opposition due to concerns about the secrecy of the negotiations, a possible regulatory race to the bottom or the privatization of public services, as well as about the power that it could give to multinationals. On the other hand, all available economic analyses had derived a positive impact, with the only exception of the one by Capaldo (2014), as reviewed in Bekkers and Rojas-Romagosa (2016).

In this paper, we offer new estimations of the potential effects that would be missed if the TTIP is not signed. We derive them for insiders and outsiders of the agreement, as well as for the world economy. To that aim, we use a Computable General Equilibrium (CGE) model of the world economy with 10 regions (US-EU28-other advanced economies-China-India-Japan-South East Asia-Latin America-Middle EastSubSaharan Africa) and 21 sectors. This methodology has become the most commonly used by economic institutions to quantify the impact of trade agreements (e.g., Francois et al., 2013; Fontagne et al., 2013; Egger et al., 2015; Petri and Plummer, 2016). A general equilibrium perspective seems mandatory for this type of analysis. Trade agreements are expected to have an impact in all sectors of the economy because the reductions in tariffs and the different types of Non-Tariff Barriers (NTBs) they entail cover all sectors. In addition, it is necessary to take into account the economic interrelationships (i.e., backward and forward linkages) across sectors, as CGE models do. Furthermore, the policy makers are interested in both the macro and microeconomic outcomes of the agreement. This contrasts with the more parsimonious approach of other methodologies, which yield estimations confined to one or two variables, such as GDP or welfare (e.g., Felbermayr et al. 2013; 2015; Alviarez et al., 2016). What is more, the detailed sectoral analysis provided by a CGE model is lacking in other more stylized general equilibrium analyses considering the interplay between FDI and trade (such as, Arkolakis et al., 2015; Burstein and Monge-Naranjo, 2009; McGrattan and Prescott, 2009; Ramondo, 2013; Ramondo and Rodríguez-Clare, 2013).

We use an innovative CGE model that introduces multinationals and FDI operating in imperfectly competitive sectors via Mode 3 (i.e., through foreign affiliates sales) within a multiregional framework. Our model follows a literature of "FDI in services" (reviewed in Tarr, 2012) in which the combination of the characteristics we have just mentioned had still not been achieved. This is of relevance for the analysis of modern agreements and even more in the case of the TTIP, since the EU and the US are both home and host of the vast majority of FDI flows and stocks in the world. For the last year available, which is 2014, they accounted for 56\% of the inward FDI stock of the world (35.2\% being in the EU and 
$20.8 \%$ in the US) and $64.7 \%$ of the world outward FDI stock ( $40.3 \%$ being owned by the EU and $24.4 \%$ by the US) ${ }^{1}$.

To the best of our knowledge, previous studies on the TTIP have not analyzed the effects of FDI. We derive that this is an important omission, since FDI has a very sizeable effect for the TTIP partners, in particular for the US. In the US, this FDI component would contribute to nearly half of the overall positive impact of TTIP, while in the EU it would be nearly one third. Interestingly, the impact of FDI would not be harmful for outsiders and would produce more than $40 \%$ of the gains after the TTIP.

The rest of the paper is organized as follows. The next section introduces the content of the TTIP providing detailed data on the costs related to impediments to trade and investment between the US and EU. Section 3 describes the model. Section 4 explains the data used and the simulations. We analyze the GDP, import and export structure of all the regions and of the world economy. Section 5 presents the micro and macroeconomic results, as well as a sensitivity analysis. We explain why an "inclusive agreement" would be beneficial not only for outsiders but also for insiders. By contrast, a "standard TTIP" could potentially, but not necessarily, have modest negative effects for outsiders, with the only exception of China, India and Japan. Section 6 summarizes the main conclusions. There are two final appendices with sectors and regions definitions, as well as an online appendix with the algebraic description of the model.

\section{The Transatlantic Trade and Investment Partnership (TTIP)}

In 2013 the US and Europe formally begun the negotiations of an ambitious agreement. Politicians declared that their main purpose was to create jobs at both sides of the Atlantic. The TTIP is based on three major pillars: 1) Increasing market access for products and services by eliminating tariffs, reducing Non-Tariff Barriers (NTBs) and opening up government procurement practices, particularly, in some US States; 2) Streamlining regulatory standards in a process that somehow could be (in part) similar to the "mutual recognition of standards" that took place in the process of European integration; 3) Establishing a set of rules on elements relevant to trade nowadays, like intellectual property, labor regulations, environmental rules, FDI and the treatment of state owned enterprises.

The frontiers between the three different pillars sometimes can be blurred. Thus, the analyses of economists have focused on what the impact of lowering NTBs faced by trade flows would be, apart from the effects of tariffs elimination. The concept of NTBs ranges from differences in packaging and labelling procedures, voltage and other technical requirements, certificates related to health, the environment and security... and red tape. Technically, NTBs have been defined as: "all non-price and non-quantity restrictions on trade in goods, services and investment, at federal and state level. This includes border measures (customs procedures, etc.) as well as behind-the-border measures flowing from domestic laws, regulations and practices' (...) Non-tariff measures and regulatory divergence are restrictions to trade in goods, services and investment at the federal or (member) state level” (Ecorys, 2009, p. xxxv). Exporters face regulatory divergences across both sides of the Atlantic, which raise the costs of exporting. Previous studies have found that the main driver of the positive impact of the TTIP was the reductions of NTBs to trade (e.g., Francois et al., 2013; Fontagne et al., 2013; Egger et al., 2015) ${ }^{2}$. In this study we also find a major impact from NTBs faced by trade, but, as noted above, the ones faced by FDI in advanced services sectors turn out to be more important for the US than NTBs related to trade and are also very important for the EU.

\footnotetext{
${ }^{1}$ The figures are authors' calculations based on the World Investment Report (UNCTAD, 2015).

${ }^{2}$ As we shall see, when the barriers related to NTBs are lowered there is an increase in the exports from the other side of the Atlantic. To a great extent, the larger the reduction in barriers, the stronger the creation of exports will be. More exports, on the other hand, imply more GDP, production and job creation. Barriers to public procurement are not the largest but still a significant part of NTBs (Francois et al., 2013). For more on procurement see also Hufbauer and Cimino-Isaacs (2015).
} 
Economists not knowing what the exact final outcome of the negotiations would have been have analyzed the potential impact of the agreement assuming that it could end up being "ambitious" or "modest". The two terms design whether the cuts in NTBs would be of $25 \%$ or $10 \%$, respectively, of what we estimate their actual levels are. We will also refer to them as deep or shallow version of the agreement. We have different sources for tariffs but estimating NTBs is a much harder task, since it involves translating laws and regulations into costs' estimations. A commonly used assessment of bilateral trade related NTBs between EU and the US is the one undertaken by Ecorys (2009). Based on business services, consultations with regulators and sector experts as well as on literature reviews, Ecorys (2009) calculated indexes of trade restrictiveness as perceived by US and EU firms across a wide variety of products. Those indexes were cross checked against OECD (2016) services restrictiveness indicators and against Product Market Regulation indexes (Koske et al., 2015). The final indexes were used to represent a NTB variable in gravity models, which were also used to estimate the costs of production related to the barriers.

Table 1. Cost reductions related to Non-Tariff Barriers (NTBs), Tariffs and Barriers to FDI that the TTIP could facilitate.

\begin{tabular}{|c|c|c|c|c|c|c|c|c|c|c|}
\hline & \multicolumn{4}{|c|}{ Transatlantic NTBs } & \multirow{2}{*}{\multicolumn{2}{|c|}{$\begin{array}{c}\text { TransatlanticTariffs } \\
100 \% \text { elimination }\end{array}$}} & \multicolumn{4}{|c|}{ Transatlantic barriers to FDI } \\
\hline & \multicolumn{2}{|c|}{ Ambitious } & \multicolumn{2}{|c|}{ Modest } & & & \multicolumn{2}{|c|}{ Ambitious } & \multicolumn{2}{|c|}{ Modest } \\
\hline & In EU & In US & In EU & In US & In EU & In US & In EU & In US & In EU & In US \\
\hline 1.Agriculture & 14.20 & 18.33 & 5.68 & 7.33 & 3.29 & 1.68 & & & & \\
\hline 2.Other primary & 14.20 & 18.33 & 5.68 & 7.33 & 0.01 & 0.02 & & & & \\
\hline 3.Food & 14.20 & 18.33 & 5.68 & 7.33 & 12.98 & 3.46 & & & & \\
\hline 4.Textiles & 4.80 & 4.18 & 1.92 & 1.67 & 6.73 & 7.77 & & & & \\
\hline 5.Wood and paper & 2.83 & 1.93 & 1.13 & 0.77 & 0.23 & 0.26 & & & & \\
\hline 6.Chemicals & 3.40 & 4.78 & 1.36 & 1.91 & 2.06 & 1.48 & & & & \\
\hline 7.Metals & 2.98 & 4.25 & I1.19 & 1.70 & 1.80 & 1.20 & & & & \\
\hline 8.Motor vehicles & 6.38 & 6.70 & 2.55 & 2.68 & 7.89 & 0.81 & & & & \\
\hline 9.Other transport & 4.70 & 4.78 & 1.88 & 1.91 & 1.18 & 0.28 & & & & \\
\hline 10.Electronics & 3.20 & 3.68 & 【1.28 & 1.47 & 0.56 & 0.37 & & & & \\
\hline 11.Other machinery & 0.00 & 0.00 & 0.00 & 0.00 & 1.30 & 0.98 & & & & \\
\hline 12.Other manufactures & 2.83 & 1.93 & 1.13 & 0.77 & 1.42 & 2.56 & & & & \\
\hline 13.Construction & 1.15 & 0.63 & 0.46 & 0.25 & 0.00 & 0.00 & & & & \\
\hline 14.Water Transport & | 2.00 & 2.00 & 10.80 & 0.80 & 0.00 & 0.00 & 2.50 & 4.25 & 1.00 & 1.70 \\
\hline 15.Air Transport & 0.50 & 0.50 & 0.20 & 0.20 & 0.00 & 0.00 & 4.50 & 5.25 & 1.80 & 2.10 \\
\hline 16.Communications & 2.93 & 0.43 & I1.17 & 0.17 & 0.00 & 0.00 & 0.45 & 0.38 & 0.18 & 0.15 \\
\hline 17.Finance & 2.83 & 7.93 & 1.13 & 3.17 & 0.00 & 0.00 & 0.50 & 0.50 & 0.20 & 0.20 \\
\hline 18.Insurance & 2.70 & 4.78 & $\mid 1.08$ & 1.91 & 0.00 & 0.00 & 2.75 & 3.00 & 1.10 & 1.20 \\
\hline 19.Business services & 3.73 & 0.98 & 1.49 & 0.39 & 0.00 & 0.00 & 7.63 & 10.00 & 3.05 & 4.00 \\
\hline 20.Personal services & 1.10 & 0.63 & 0.44 & 0.25 & 0.00 & 0.00 & & & & \\
\hline 21.Other services & 1.10 & 0.63 & 0.44 & 0.25 & 0.00 & 0.00 & & & & \\
\hline Average Manufactures & 5.38 & 6.35 & 2.15 & 2.54 & & & & & & \\
\hline Average Services & | 2.13 & 2.23 & 0.85 & 0.89 & & & & & & \\
\hline
\end{tabular}

Source: Ecorys (2009), Fontagne et al. (2013) and Francois and Machin (2014) for the NTBs; Narayanan et al. (2015) for the tariffs and Jafari and Tarr (2015) for barriers to FDI.

Table 1 offers the cost savings in exporting that could be achieved after the agreement across 21 sectors in which the US, EU and the rest of regions in our model are split ${ }^{3}$. In its first four columns, it presents the estimated cost reductions related to NTBs in trade flows. The columns with the label "ambitious" show a $25 \%$ reduction in the total costs that the barrier implies, while the ones labelled "modest" show a $10 \%$ reduction ${ }^{4}$. Note that costs savings in manufacturing sectors, tend to be higher than those of services.

\footnotetext{
${ }^{3}$ It is precisely the data availability of NTBs related to trade what makes us split our economies into these 21 sectors. Appendix 1 presents the sectors' mappings to several classifications.

${ }^{4}$ The reader can check that multiplying by 4 (10) the ambitious (modest) costs of NTBs yields the total costs of these barriers displayed in Table 2 of Francois et al. (2013, p. 20), which stem, in turn, from Ecorys (2009). However, Francois et al. (2013) do not offer barriers for “Agriculture”, "Other manufacturing” and "Other services” -they have included them in Egger et al. (2015) for the two former sectors-. For those sectors we take the estimations
} 
The next two columns of Table 1 refer to cost savings due to the total elimination of tariffs. There are considerably larger savings in costs related to NTBs than in the case of tariffs. Finally, the last four columns of Table 1 display the "Barriers to FDI" in advanced business services, since they are not available for the rest ${ }^{5}$. Jafari and Tarr (2015) have recently estimated these barriers that foreign firms face when they enter markets abroad. For the provision of services across borders, the physical presence of firms (i.e., the operations of affiliates) seems more important than in the case of manufacturing goods. The latter can be exported more easily than services.

The reductions in barriers to FDI (between the US and Europe) imply rather low cost savings, except in the business sectors and in air transport. In fact, the cost reductions we assume are a rather conservative decrease. Again, ambitious and modest stand for $25 \%$ and $10 \%$ reductions, as they do in the case of NTBs. Those percentages are smaller than the common 50\% cuts that have been estimated in the few CGE models of "FDI in services" (Tarr, 2012). Francois et al. (2013) have also estimated the barriers faced by FDI between the US and Europe. However, that information is not publicly available. But they do mention, in Chapter 6, that a 25\% reduction of barriers faced by FDI would be realistic. Indeed, they econometrically estimate the impact of that reduction. But, as they themselves recognize, the results are not comparable to what they obtain from their CGE for trade NTBs and tariffs, due to the different methodological approach. By contrast, in this paper the results obtained from the different components of the TTIP are fully comparable since they are all derived within the same CGE model. In a latter paper using the same Francois et al. (2013) model and also the database from Jafari and Tarr (2015), NTBs faced by trade (not by foreign affiliates sales which are absent in the model) are cut by 50\%, with the only exception of Finance and Insurance for which there are no reductions at all.

The main take away from Table 1 is that the cost reductions associated with the fall in barriers to FDI and trade are very heterogeneous across sectors and types of barriers. When we explain the simulations and the results we will come back to this table because the degree of cost savings is an important determinant of the differential impact of the TTIP across sectors.

\section{The model}

CGE models have become very popular for the analysis of trade agreements. They include data on many macro and microeconomic variables in a robust theoretical framework (Shoven and Whalley, 1984). In so doing, they allow to derive quantitative estimations along several dimensions, which are important to take policy decisions. As noted in the introduction, a salient feature in comparison with other well-known robust general equilibrium analyses of FDI and trade is their detailed sectoral analysis, which captures intermediate linkages.

This section includes a non-technical overview of the model. A more detailed description is provided as an online appendix. The current model extends the multiregional CGE of Balistreri et al. (2015) along several dimensions. The original Balistreri et al. (2015) is a step forward to a multiregional CGE in a literature of "FDI in services" which had been previously constrained to single country models. These include simulations of the impact of the accession of Russia to the WTO (Rutherford and Tarr, 2008) and other integration of African and East European countries (e.g., Latorre, 2016). In those single country applications, the sectors with FDI, i.e. advanced business sectors, produce in a framework of DixitStiglitz monopolistic competition, following Krugman (1980) and Helpman and Krugman (1985). Intuitively, this implies that a growing number of varieties of a product (either through more domestic firms, exports or a higher number of foreign affiliates) leads to potential increases in both consumers' welfare and producers' productivity. The latter effect arises because with more firms and higher

used by the CEPII (Fontagne et al., 2013, p. 8), which are the same ones used in Francois and Machin (2014, p. 23). From this latter study, we also obtain the trade NTBs for "Other manufacturing” and "Other services".

${ }^{5}$ The fact that the TTIP includes explicitly investment and arbitration mechanisms allowing foreign multinationals to sue governments has become one of its most contentious issues. It lies outside the scope of this paper to develop the important related legal aspects. We focus on the economic impact of FDI. A good starting point to think about pros and cons of dispute settlement systems is offered by Lawrence (2003). 
competition the intermediates they produce become cheaper, which helps to save costs in production for the firms using them. This mechanism resembles the empirical evidence of FDI in services leading to higher productivity in other sectors of the economy using panel data and controlling for the endogeneity of FDI (e.g., Fernandes and Paunov, 2012; Arnold et al., 2008) and has been well established more generally in the literature (e.g., Broda and Weinstein, 2006 and Goldberg et al, 2009). This sort of effects cannot be modelled in a one-sector model, as noted by Egger et al. (2015).

The Dixit-Stiglitz mechanism in previous studies is present only in manufacturing sectors while it is absent in the FDI services sectors of the multiregional model of Balistreri et al. (2015) ${ }^{6}$. We extend this latter model with two new features. First, while preserving the multiregional framework, we introduce the Dixit-Stiglitz monopolistic competition with endogenous productivity effects in the advanced services sectors with FDI, as noted above. Second, we develop a steady state formulation following the specification of previous TTIP assessments (e.g., Francois et al., 2013 and Egger et al, 2015), going beyond the static framework of Balistreri et al. (2015).

The main characteristics of our model can be briefly summarized as follows. As is common in the analysis of the TTIP, the model has one representative consumer in each region whose income stems from the remuneration of all factors of production. Because the model aims at analyzing trade policies, we use the common specification that it is private consumption which adjusts to the variations of income of the representative agent. Public consumption remains constant in real terms to avoid the distortions that its variation would produce.

The model has a rich set of taxes (on production and consumption) that vary according to the different sectors. It also includes tariffs and subsidies as well as the different types of NTBs displayed in Table 1. NTBs bring about efficiency losses (red tape is inefficient in many cases) but may also generate rents for different agents (they protect the insider firms, who facing weak competition charge higher prices than in the case of perfect competition). Ecorys (2009) estimated the share of rents and efficiency losses that were behind the NTBs between Europe and the US. On average, despite some variation across sectors, $60 \%$ of the costs of the NTBs were found to be efficiency losses, while $40 \%$ would create rents. Additionally, they calculated that $2 / 3$ of the rents were earned by importers and $1 / 3$ by exporters. The $60 \%$ of efficiency losses are modelled as iceberg costs, using a common approach.

On the other hand, the model has three types of sectors: 1) Manufacturing sectors which operate in an imperfect competition framework (chemicals, electronics, automobiles, textiles and other manufacturing); 2) Imperfectly competitive advanced services sectors with multinationals and foreign direct investment (banking, insurance, business services, air and water transport and telecommunications); 3) Perfect competition sectors: agriculture and the rest of manufacturing and services sectors not included in the previous two groups of imperfectly competitive sectors.

The operations of multinationals are an important element of modern trade agreements. However, very few CGE models incorporate them. See Tarr (2012) and Latorre (2009) for a summary of the available models ${ }^{7}$. Our model differentiates the impact of FDI flows according to the services' sector to which they accrue, which is in accordance with the fact that the effects of multinationals vary across sectors (Smarzinska, 2004; Latorre and Hosoe, 2016; Zhou and Latorre, 2014a,b; Latorre, 2013). We also include the impact of profit repatriation that is assumed to be $50 \%$ in all the results we analyze. This issue is of importance according to previous evidence (Latorre et al., 2009; Gómez-Plana and Latorre, 2014).

In the perfect competition sectors firms produce with constant returns to scale. Products differ according to their country of origin. In other words, an Armington specification is used so that each region in the model produces and specific variety, which is an imperfect substitute for varieties coming from other

\footnotetext{
${ }^{6}$ Recently, Oleseyuk (2015) has also introduced FDI in a framework of imperfectly competition, but FDI is modelled only in the region in which the analysis focuses, namely, Ukraine, while it is absent in the rest of regions in the model. Most notably, Oleseyuk's model includes heterogeneous firms in manufacturing in its multiregional framework.

${ }^{7}$ Fukui and Lakatos (2014) and Ciuriak et al. (2014) are notable exceptions of a CGE approach including FDI, however, their multi-regional framework is more simplified than ours due to its climate of perfect competition with no economies of scale.
} 
regions. This Armington assumption grasps the empirical evidence that countries trade different varieties of the same good or service.

\section{Data Sources and simulations}

Some of the data sources have already been detailed in the section 2. However, the base data for the majority of micro and macroeconomic variables, as well as the input-output data of the model come from the latest version of the GTAP Database (GTAP 9, Narayanan et al., 2015). This database is commonly

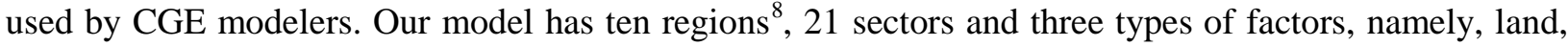
capital and labor.

GTAP 9 resembles the world economy in 2011, and we conduct the forward calibration by using IMF (2015) GDP projections for 2020 (following the technique described in Böhringer et al. (2009)). This year looked like a reasonable benchmark for the TTIP to have already been agreed, before the elections in the US. Therefore it will be our reference year for the simulations. Data on the sales of foreign multinationals across the different regions and services' sectors are from the US International Trade Commission Database (Fukui and Lakatos, 2012).

In Tables 2 and 3 we provide an overview of the productive and trade structure of the different regions. We present their percentage shares in GDP (Table 2) as well as in overall imports and exports (Table 3) in 2020. The last column offers the shares in the world and the last rows some summarizing figures of the weight of "all manufactures", "all services" and a "total” of the 21 sectors.

The first row and last column of Table 2 show that the weight of agriculture in the world is of $5.3 \%$ of total GDP. However, several of the regions considered exhibit quite large shares in this sector. The most extreme case is the one of Sub-Saharan Africa (19.4\%), followed by India (18.9\%), Southeast Asia (13.5\%) and China (10.6\%). In the same line, the world is a services society with a $62.6 \%$ share, which clearly prevails over the weight of manufactures (32.1\%). Across all regions services do also prevail as the main source of GDP with the only exception of the Middle-East (46.9\% or services versus $47.6 \%$ of manufactures). However, the overall weight of services varies considerably among regions with the most developed areas, logically, being more specialized in them -Japan (76.9\%), US (74.7\%), EU (69.0\%) and other advanced countries (67.8\%)- and the least developed ones exhibiting the lowest shares -SubSaharan Africa (45.5\%), China (46\%), Southeast Asia (46.8\%), Middle-East 46.9\%) and India (54.7\%). Latin America is close to the world average in services (62.1\%).

The structure of the GDP contrasts sharply with the one of imports and exports, which appears in Table 3. Again the last column offers the importance of each sector in total world trade (exports and imports coincide, of course, in this column). World trade is clearly dominated by manufacturing products (82.6\%), while the weight of services is $14.8 \%$ and agriculture would account for the remaining $2.7 \%$. Even though the world is specialized in services, in terms of GDP, this is clearly not the case in trade. We see, however, that the EU stands out across regions with a larger share of trade in services sectors (22.3\% and $22.1 \%$ of its exports and imports, respectively). Exports of services also account for an important share of total exports in the US (20\%) and even more in India (23.7\%), with less important shares in the import side of services in both areas (14.1\% and $12.1 \%$ of their total imports, respectively). Other advanced countries also have more trade in services than other areas, although they are less specialized in them than the EU.

The last row of Table 3 shows the weight of total exports and imports of each region in world trade. We can see that the TTIP area accounts for the $18.4 \%$ and $12.5 \%$ of total exports from the EU and US, respectively (i.e., $30.9 \%$ of world exports). Their overall share is larger in imports, $17.5 \%$ (EU) and

\footnotetext{
${ }^{8}$ Appendix 2 presents the country composition of each of the regions.
} 
Table 2. GDP structure of the world and the different regions in 2020

\begin{tabular}{|c|c|c|c|c|c|c|c|c|c|c|c|}
\hline & $\mathrm{EU}$ & US & China & Japan & India & Latin America & Other advanced & Southeast Asia & Sub-Saharan A. & Middle-East & World \\
\hline 1.Agriculture & 2.0 & 1.4 & $\square 10.6$ & 1.4 & 18.9 & 6.3 & 2.2 & 13.5 & 19.4 & 5.5 & 5.3 \\
\hline 2.Other primary & 0.9 & 1.7 & 3.9 & 0.1 & 2.3 & 5.3 & 5.2 & 8.4 & 14.2 & 24.2 & ] 5.1 \\
\hline 3.Food & 3.2 & 1.9 & 2.6 & 2.2 & 3.1 & 4.4 & 1.9 & 5.2 & 4.9 & 3.4 & 2.9 \\
\hline 4.Textiles & 1.2 & 0.7 & 2.7 & 0.3 & 1.7 & 1.6 & 0.7 & 2.9 & 1.1 & 1.4 & 1.3 \\
\hline 5.Wood and paper & 2.3 & 2.4 & 1.6 & 1.3 & 0.7 & 1.6 & 1.7 & 1.7 & 1.2 & 0.8 & 1.8 \\
\hline 6.Chemicals & 3.5 & 2.8 & 5.0 & 2.3 & 2.8 & 3.6 & 3.1 & 4.8 & 1.6 & 3.3 & [] 3.4 \\
\hline 7.Metals & 2.8 & 1.9 & 4.9 & 2.5 & 2.2 & 2.5 & 2.8 & 2.1 & 2.7 & 2.6 & 2.8 \\
\hline 8.Motor vehicles & 1.6 & 0.9 & 1.6 & 1.6 & 0.6 & 1.4 & 1.1 & 1.2 & 0.6 & 0.8 & 1.2 \\
\hline 9.Other transport & 0.6 & 0.8 & 0.8 & 0.3 & 0.4 & 0.3 & 0.7 & 0.6 & 0.6 & 0.3 & 0.6 \\
\hline 10.Electronics & 0.8 & 0.5 & 2.4 & 1.7 & 0.3 & 1.2 & 2.5 & 2.1 & 0.4 & 0.6 & 1.2 \\
\hline 11.Other machinery & 4.2 & 3.6 & 5.6 & 3.2 & 1.7 & 1.7 & 3.1 & 2.1 & 1.2 & 1.8 & [] 3.4 \\
\hline 12.Other manufactures & 1.6 & 0.8 & 4.5 & 1.0 & 2.5 & 1.6 & 1.3 & 1.9 & 1.2 & 1.6 & 1.8 \\
\hline 13.Construction & 6.5 & ] 6.1 & 7.7 & 5.1 & D 8.1 & 6.5 & 6.1 & 6.7 & 5.5 & 6.8 & 6.5 \\
\hline 14.Water Transport & 0.4 & 0.3 & 1.3 & 0.7 & 0.7 & 0.2 & 0.6 & 0.7 & 0.2 & 0.6 & 0.6 \\
\hline 15.Air Transport & 0.4 & 0.5 & 0.3 & 0.2 & 0.2 & 0.3 & 0.5 & 0.6 & 0.4 & 0.5 & 0.4 \\
\hline 16.Communications & 2.8 & 2.4 & 2.0 & 2.3 & 1.7 & 2.7 & 2.3 & 1.6 & 1.9 & 1.5 & 2.3 \\
\hline 17.Finance & 4.1 & 8.0 & 4.7 & 4.2 & ] 5.2 & 3.6 & 5.4 & 2.6 & 2.1 & 3.8 & ] 5.0 \\
\hline 18.Insurance & 1.3 & 1.9 & 0.5 & 1.6 & 1.1 & 0.9 & 1.3 & 0.6 & 2.1 & 0.3 & 1.2 \\
\hline 19.Business services & $\square 15.7$ & $\square 10.4$ & 5.4 & 11.3 & ] 5.2 & 7.9 & 11.9 & 3.3 & 6.1 & 5.2 & $\square 9.6$ \\
\hline 20.Personal services & 3.5 & 3.3 & 2.3 & 3.4 & 0.3 & 3.7 & 2.5 & 2.3 & 2.3 & 1.4 & 2.8 \\
\hline 21.Other services & 40.8 & 47.8 & 29.5 & 53.3 & 40.4 & 42.7 & 43.4 & 35.3 & 30.3 & 33.6 & 40.7 \\
\hline All manufactures & 29.1 & 24.0 & 43.4 & 21.8 & 26.4 & 31.6 & 30.1 & 39.7 & 35.1 & 47.6 & 32.1 \\
\hline All services & 69.0 & 74.7 & 46.0 & 76.9 & 54.7 & 62.1 & 67.8 & 46.8 & 45.5 & 46.9 & 62.6 \\
\hline Total share in the world & $\square 19.0$ & 21.4 & 15.2 & 6.9 & 4.1 & 8.0 & 10.0 & 3.0 & 2.5 & 9.8 & 100.0 \\
\hline
\end{tabular}

Source: Authors' estimations based on Narayanan et al. (2015) and in IMF (2015) for the projections. 
Table 3. Export and Import structure of the world and the different regions in 2020.

\begin{tabular}{|c|c|c|c|c|c|c|c|c|c|c|c|c|c|c|c|c|c|c|c|c|c|}
\hline & \multicolumn{2}{|c|}{ EU } & \multicolumn{2}{|c|}{ US } & \multicolumn{2}{|c|}{ China } & \multicolumn{2}{|c|}{ Japan } & \multicolumn{2}{|c|}{ India } & \multicolumn{2}{|c|}{ Latin America } & \multicolumn{2}{|c|}{ Other advanced } & \multicolumn{2}{|c|}{ Southeast Asia } & \multicolumn{2}{|c|}{ Sub-Saharan A. } & \multicolumn{2}{|c|}{ Middle-East } & \multirow{2}{*}{$\begin{array}{l}\text { World } \\
\text { Trade }\end{array}$} \\
\hline & Exports & Imports & Exports & Imports & Exports & Imports & Exports & Imports & Exports & Imports & Exports & Imports & Exports & Imports & Exports & Imports & Exports & Imports & Exports & Imports & \\
\hline 1.Agriculture & 1.2 & | 2.4 & 5.2 & 1.6 & 0.9 & 4.2 & 0.2 & 2.9 & 3.9 & 1.5 & 9.5 & 2.4 & 2.2 & 1.8 & 3.2 & 3.5 & 6.1 & 3.0 & 1.1 & 4.0 & 2.7 \\
\hline 2.Other primary & 1.1 & 17.5 & 1.5 & 13.4 & 0.3 & 23.0 & 0.1 & 24.7 & 4.8 & 33.6 & 22.4 & 3.4 & 11.3 & 12.0 & 12.1 & 6.9 & 60.3 & 4.2 & 58.2 & 1.7 & 14.5 \\
\hline 3.Food & 4.3 & 2.8 & 4.1 & 3.4 & 2.0 & 2.4 & 0.5 & 5.8 & 5.7 & 2.2 & 10.3 & 3.6 & 3.1 & 3.7 & 10.5 & 4.6 & 2.2 & 9.7 & 1.2 & 6.6 & 3.8 \\
\hline 4.Textiles & 2.6 & 6.3 & 1.2 & 5.5 & 15.9 & 2.2 & 1.3 & 5.3 & 10.4 & 1.4 & 2.4 & 5.1 & 2.3 & 3.7 & 10.5 & 5.6 & 1.0 & 5.0 & 2.7 & 6.3 & 4.7 \\
\hline 5.Wood and paper & 3.0 & 1.8 & 2.8 & 2.9 & 3.8 & 2.3 & 0.9 & 2.5 & 0.6 & 1.2 & 2.4 & 2.4 & 2.3 & 2.7 & 3.5 & 1.9 & 0.8 & 2.2 & 0.6 & 2.8 & 2.3 \\
\hline 6.Chemicals & 17.7 & 14.4 & 22.0 & 13.5 & 10.7 & 15.2 & 15.3 & 13.8 & 23.2 & 12.3 & 8.0 & 24.7 & 16.6 & 15.8 & 13.3 & 18.9 & 2.8 & 18.2 & 15.5 & 14.4 & 15.4 \\
\hline 7.Metals & 6.9 & 6.4 & 6.4 & 5.7 & 7.6 & 7.4 & 9.7 & 5.3 & 5.7 & 15.6 & 10.8 & 6.2 & 10.2 & 10.3 & 5.0 & 10.8 & 13.9 & 5.7 & 4.8 & 7.6 & 7.7 \\
\hline 8.Motor vehicles & 9.1 & 2.7 & 6.7 & 8.5 & 2.1 & 4.7 & 17.2 & 2.0 & 2.2 & 1.4 & 7.1 & 8.2 & 5.0 & 6.1 & 2.3 & 3.6 & 1.6 & 7.0 & 1.0 & 9.1 & 5.6 \\
\hline 9.Other transport & 3.8 & 2.9 & 5.1 & 2.0 & 2.2 & 1.4 & 2.5 & 1.2 & 1.2 & 1.4 & 1.2 & 3.8 & 2.9 & 2.5 & 0.7 & 3.7 & 0.3 & 6.5 & 0.4 & 2.8 & 2.5 \\
\hline 10.Electronics & 3.3 & 7.2 & 5.2 & 11.4 & 23.3 & 10.8 & 10.2 & 8.5 & 1.6 & 4.7 & 6.0 & 7.7 & 11.3 & 8.2 & 15.4 & 11.7 & 0.1 & 3.7 & 0.4 & 4.8 & 8.5 \\
\hline 11.Other machinery & 19.9 & 10.1 & 17.3 & 13.8 & 19.4 & $\square 17.4$ & 29.7 & 10.1 & 4.9 & 10.0 & 7.8 & 18.9 & 14.2 & 14.5 & 8.2 & 15.8 & 1.1 & 14.1 & 1.5 & 17.0 & 14.1 \\
\hline 12.Other manufactures & 2.7 & 2.7 & 2.1 & 4.0 & 6.4 & 0.9 & 2.3 & 1.9 & 11.8 & 2.4 & 0.9 & 2.1 & 1.8 & 3.2 & 2.4 & 1.9 & 0.7 & 2.7 & 0.9 & 4.1 & 2.7 \\
\hline 13.Construction & 1.2 & 0.8 & 0.4 & 0.1 & 0.3 & 0.3 & 1.4 & 1.2 & 0.3 & 0.2 & 0.2 & 0.2 & 0.6 & 0.3 & 0.5 & 0.7 & 0.1 & 1.4 & 0.4 & 2.0 & 0.6 \\
\hline 14.Water Transport & 1.2 & 0.8 & 0.0 & 0.1 & 0.1 & 0.1 & 0.4 & 1.3 & 0.6 & 0.6 & 0.9 & 0.7 & 0.5 & 1.1 & 0.7 & 0.4 & 0.4 & 0.4 & 0.5 & 0.3 & 0.5 \\
\hline 15.Air Transport & 2.7 & 2.1 & 1.7 & 1.6 & 0.3 & 0.5 & 1.0 & 1.8 & 0.4 & 0.9 & 1.0 & 1.6 & 1.4 & 1.7 & 2.1 & 1.0 & 1.4 & 1.9 & 1.4 & 1.3 & 1.5 \\
\hline 16.Communications & 0.4 & 0.8 & 0.2 & 0.2 & 0.1 & 0.2 & 0.1 & 0.2 & 0.8 & 0.2 & 0.4 & 0.1 & 0.3 & 0.4 & 0.6 & 0.3 & 0.5 & 0.3 & 0.7 & 0.4 & 0.4 \\
\hline 17.Finance & 1.5 & 2.2 & 2.0 & 1.1 & 0.1 & 0.2 & 0.6 & 0.9 & 0.8 & 1.3 & 0.4 & 0.2 & 1.5 & 0.7 & 0.3 & 0.3 & 0.4 & 0.2 & 0.5 & 1.0 & 1.0 \\
\hline 18.Insurance & 1.2 & 0.4 & 1.1 & 1.4 & 0.1 & 0.6 & 0.4 & 0.5 & 0.8 & 0.5 & 0.5 & 0.4 & 0.8 & 0.4 & 0.3 & 0.4 & 0.4 & 0.4 & 0.3 & 0.7 & 0.6 \\
\hline 19.Business services & 7.4 & 6.8 & 5.3 & 4.0 & 1.2 & 1.5 & 2.2 & 4.6 & $\square 16.1$ & 5.3 & 2.7 & 2.6 & 4.7 & 4.0 & 2.1 & 3.8 & 1.4 & 5.8 & 2.7 & 4.7 & 4.3 \\
\hline 20.Personal services & 1.4 & 1.2 & 1.9 & 0.6 & 0.3 & 0.4 & 0.3 & 0.8 & 0.2 & 0.4 & 0.9 & 1.1 & 0.7 & 1.2 & 0.9 & 0.8 & 0.8 & 0.9 & 0.5 & 1.2 & 0.9 \\
\hline 21.Other services & 7.6 & 7.6 & 7.9 & 5.2 & 2.7 & 4.5 & 3.7 & 4.4 & 4.1 & 2.7 & 4.4 & 4.7 & 6.4 & 5.8 & 5.5 & 3.6 & 3.8 & 6.9 & 4.9 & 7.1 & 5.6 \\
\hline All manufactures & 75.5 & 75.5 & 74.9 & 84.3 & 94.0 & 87.8 & 91.1 & 82.4 & 72.4 & 86.5 & 79.3 & 86.3 & 81.6 & 82.8 & 84.4 & 85.9 & 84.9 & 80.2 & 87.5 & 79.2 & 82.6 \\
\hline All services & 23.3 & 22.1 & 20.0 & 14.1 & 5.1 & 8.0 & 8.8 & 14.7 & 23.7 & 12.1 & 11.2 & 11.3 & 16.3 & 15.4 & 12.5 & 10.6 & 9.0 & 16.8 & 11.4 & 16.8 & 14.8 \\
\hline Total share in the world & 18.4 & 17.5 & 12.5 & 17.1 & 13.7 & 14.9 & 6.0 & 5.4 & 2.6 & 5.1 & 6.9 & 5.9 & 17.6 & 15.5 & 5.7 & 5.2 & 3.1 & 3.1 & 13.4 & 10.3 & 100.0 \\
\hline
\end{tabular}

Source: Authors' estimations based on Narayanan et al. (2015) and in IMF (2015) for the projections. 
$17.1 \%$ (US), which adds up to $34.6 \%$ of total world imports ${ }^{9}$. This reveals the potential of the TTIP to have an important effect in world trade.

Tables 4 and 5 show the regions' shares in bilateral imports and exports across sectors of the TTIP partners (i.e., the weight of each of the trading partners in total US and EU trade). The US and EU are very integrated in their trade flows, particularly in services. This trend is more intense in services in the US (Table 4), in which the EU is by far the most important trade partner. Indeed, the EU accounts for $39.6 \%$ and $40.2 \%$ of total US imports and exports in services, respectively. By contrast, for manufacturing imports in the US other areas such as other advanced countries, China and Latin America are more important sources than the EU, with shares of $21.7 \%, 20.2 \%$ and $17.9 \%$ (versus $16.1 \%$ from the EU). Regarding manufacturing exports, the US is also very heavily integrated with other advanced countries and Latin America with shares of $28.4 \%$ and $21.7 \%$, which exceed the one of the EU (19.7\%).

We turn now to the trading partners of the EU (Table 5). The US is the main provider of imports in services (27.8\%) and the second most important destination of its services exports (21.6\%), after other advanced countries (24.9\%). These US shares in services exceed considerably the ones in manufacturing, in which the US accounts for $16.7 \%$ and $13.6 \%$ of total EU exports and imports, respectively. Indeed, in manufacturing the most important trade partner for Europe is the Middle-East region (26.4\% and 26.2\% of its imports and exports, respectively).

China also surpasses the weight of the US in manufacturing imports in the EU (18.5\% versus $13.6 \%)$. But the US is a more important destination of EU exports than China (16.7\% versus $13.0 \%)$.

In sum, all the figures we have just described reveal the following. Other advanced economies stand out in its integration with the TTIP area among outsiders. Latin America has stronger ties with the US than with the EU. The Middle-East region plays a prominent role in trade with the EU in services, and even more in manufacturing.

The TTIP would imply three potential reductions of trade and investment barriers, whose exact costs' reductions were displayed in Table 1 . These elements constitute what we will call the "standard TTIP" in order to differentiate it from the "inclusive TTIP" that will be analyzed later on. Let us briefly summarize how those components of the agreement will be labelled in the results we are about to analyze:

1) "NTBs": in this simulation the US-EU bilateral trade related NTBs are lowered in all the 21 sectors simultaneously. The reductions in costs are exactly the ones displayed in the first four columns of Table 1. So, for example, in an ambitious simulation the European agricultural firms would save $18.33 \%$ of their total costs of exporting to the other side of the Atlantic, while US agricultural firms would save $14.20 \%$. In a modest simulation the reductions would be of $7.33 \%$ and $5.68 \%$, respectively. The same idea would apply for reductions in the rest of sectors.

2) "Tariffs": in this scenario there is a total elimination of US and EU bilateral tariffs, that, as is well known, only affects agricultural and manufacturing sectors. For example, in agriculture the savings of US firms would be $3.29 \%$ when they export to the EU, while all EU firms would save $1.68 \%$ when exporting to the US.

3) "FDI": the barriers that foreign firms experience to operate at the other side of the Atlantic are reduced in this simulation. Note that these barriers affect only the group of services that we have called "advanced services" (i.e., not all services sectors). The largest reduction appears in business services, US multinationals could save $7.63 \%$ in their operations in the EU in the ambitious scenario, while EU multinationals could save $10.00 \%$ of costs in the US.

4) "Total": this simulation includes the simultaneous interaction of the three previous ones (i.e., of NTBs, tariffs and FDI altogether).

\footnotetext{
${ }^{9}$ The EU numbers will be larger once we consider trade within the EU. Of course, this also applies to other regions comprising several countries.
} 
Table 4. Regions' shares in US bilateral trade in 2020.

\begin{tabular}{|c|c|c|c|c|c|c|c|c|c|c|c|c|c|c|c|c|c|c|}
\hline & \multicolumn{2}{|c|}{ EU } & \multicolumn{2}{|c|}{ China } & \multicolumn{2}{|c|}{ Japan } & \multicolumn{2}{|c|}{ India } & \multicolumn{2}{|c|}{ Latin America } & \multicolumn{2}{|c|}{ Other advanced } & \multicolumn{2}{|c|}{ Southeast Asia } & \multicolumn{2}{|c|}{ Sub-Saharan A. } & \multirow{2}{*}{\multicolumn{2}{|c|}{$\begin{array}{c}\text { Middle-East } \\
\text { Exports Imports }\end{array}$}} \\
\hline & Exports & Imports & Exports & Imports & Exports & Import & Export & s Imports & Exports & Imports & Exports & Imports & Exports & Imports & Exports & Imports & & \\
\hline 1.Agriculture & 6.4 & 4.3 & 28.9 & 3.6 & 9.4 & 0.2 & 0.8 & 2.8 & 15.7 & 57.7 & 17.5 & 18.8 & 5.6 & 6.3 & 4.9 & 4.6 & 1.8 & $\square 10.7$ \\
\hline 2.Other primary & 23.7 & 0.4 & $\square 12.2$ & 0.2 & 5.2 & 0.0 & 2.8 & 0.0 & 16.9 & 23.5 & 26.6 & 19.0 & 0.6 & 0.4 & 0.4 & 23.1 & 33.4 & 11.7 \\
\hline 3.Food & 8.4 & 22.7 & 8.9 & 7.3 & 11.3 & 0.9 & 0.5 & 2.9 & 24.1 & 23.3 & 29.8 & 26.9 & 5.0 & $\square 13.1$ & 2.6 & 1.0 & 1.8 & 9.5 \\
\hline 4.Textiles & 12.5 & 6.3 & 10.3 & 41.8 & 2.7 & 0.5 & 1.2 & 5.6 & 41.9 & $\square 12.3$ & 21.9 & 6.8 & 3.0 & 19.8 & 1.5 & 0.8 & 6.0 & 5.0 \\
\hline 5.Wood and paper & $\square 12.7$ & 11.0 & 19.7 & 34.4 & 3.9 & 1.1 & 2.6 & 0.5 & 21.4 & $\square 13.8$ & 30.2 & 31.6 & 2.6 & 6.8 & 1.4 & 0.3 & 0.5 & 5.6 \\
\hline 6.Chemicals & 24.3 & 32.6 & ] 8.4 & 9.6 & 3.9 & 4.2 & 2.2 & 3.2 & 28.7 & $\square 12.9$ & 22.3 & 25.4 & 1.9 & 3.2 & 2.5 & 0.8 & 7.9 & 5.9 \\
\hline 7.Metals & 18.8 & 14.4 & 11.3 & 14.0 & 2.2 & 3.9 & 3.6 & 1.6 & 17.6 & 24.9 & 33.1 & 30.7 & 3.9 & 1.9 & 1.7 & 3.2 & 5.4 & 7.9 \\
\hline 8.Motor vehicles & 8.9 & 18.6 & 8.3 & 4.0 & 1.2 & 18.4 & 0.4 & 0.4 & 21.6 & 24.8 & 43.0 & 31.8 & 1.6 & 0.4 & 4.1 & 1.2 & 0.4 & 10.8 \\
\hline 9. Other transport & 33.6 & 45.0 & 11.5 & 6.8 & 5.2 & $\square 10.0$ & 1.4 & 2.1 & 8.1 & 7.7 & 25.2 & 25.9 & 4.3 & 0.9 & 2.1 & 0.3 & 1.3 & 8.7 \\
\hline 10.Electronics & 16.9 & 3.2 & D15.1 & 51.7 & 5.7 & 3.4 & 1.9 & 0.2 & 16.6 & 16.8 & 27.4 & 16.5 & 11.4 & 8.2 & 0.8 & 0.0 & 0.1 & 4.3 \\
\hline 11.Other machinery & 18.1 & 24.0 & $\square 11.5$ & 24.5 & 4.0 & $\square 11.5$ & 2.0 & 0.9 & 20.0 & 17.8 & 30.2 & 17.8 & 3.3 & 3.0 & 2.5 & 0.2 & 0.4 & 8.4 \\
\hline 12.Other manufactures & 25.9 & 16.8 & 8.5 & 39.7 & 3.5 & 2.5 & 7.9 & 9.0 & $\square 13.5$ & 5.9 & 31.3 & 19.0 & 2.2 & 3.8 & 1.7 & 1.4 & 1.8 & 5.4 \\
\hline 13.Construction & 24.5 & 26.3 & 1.9 & 8.7 & 21.2 & 18.7 & 0.4 & 0.3 & 1.1 & 1.4 & 4.4 & 18.2 & 4.3 & 6.3 & 5.5 & 1.0 & 19.0 & 36.8 \\
\hline 14.Water Transport & 19.7 & 18.3 & 2.6 & 10.3 & ] 8.2 & 1.8 & 3.4 & 2.5 & 7.1 & 6.5 & 27.9 & 20.2 & 2.5 & 12.2 & 3.1 & 2.4 & 25.9 & 25.5 \\
\hline 15.Air Transport & 40.7 & 44.2 & 2.8 & 3.2 & 12.3 & 4.5 & 1.6 & 0.3 & 8.7 & 4.5 & 18.1 & 22.1 & 3.8 & 7.6 & 3.3 & 2.7 & 10.9 & 8.7 \\
\hline 16.Communications & 44.9 & 39.8 & 6.2 & 4.4 & 3.2 & 2.2 & 3.6 & 5.8 & 3.5 & 5.9 & 23.8 & 19.7 & 3.0 & 4.7 & 2.0 & 2.4 & 15.0 & 9.8 \\
\hline 17.Finance & 53.6 & 60.4 & 1.9 & 1.1 & 6.3 & 5.5 & 4.6 & 1.6 & 3.5 & 3.1 & 18.1 & 21.5 & 1.6 & 0.9 & 1.5 & 0.6 & 5.3 & 9.0 \\
\hline 18.Insurance & 27.8 & 60.9 & 6.0 & 0.5 & 9.8 & 2.4 & 3.0 & 0.5 & 9.3 & 3.0 & 24.4 & 25.0 & 3.7 & 1.6 & 3.4 & 0.9 & 5.1 & $\square 12.7$ \\
\hline 19.Business services & 49.0 & 29.5 & 2.9 & 4.9 & $\square 11.2$ & 3.3 & 5.1 & 20.4 & 2.5 & 4.7 & 11.9 & 26.3 & 3.2 & 1.8 & 3.5 & 0.8 & 8.2 & $\square 10.8$ \\
\hline 20.Personal services & 30.1 & 39.4 & 4.8 & 6.7 & 8.2 & 3.1 & 4.1 & 0.1 & 6.5 & 13.9 & 28.5 & 21.6 & 2.7 & 5.3 & 3.1 & 3.7 & 6.2 & 12.1 \\
\hline 21.Other services & 32.1 & 33.4 & 4.3 & 4.8 & 5.7 & 3.0 & 3.4 & 2.4 & 6.2 & 8.1 & 23.4 & 27.2 & 2.4 & 4.9 & 4.3 & 2.8 & $\square 13.5$ & 18.1 \\
\hline All manufactures & 19.7 & 16.1 & 10.6 & 20.2 & 4.2 & 5.6 & 2.1 & 1.8 & 21.7 & 17.9 & 28.4 & 21.7 & 3.4 & 4.6 & 2.3 & 4.3 & 7.7 & 7.6 \\
\hline All services & 40.2 & 39.6 & 3.7 & 3.9 & 8.1 & 3.4 & 3.9 & 6.6 & 5.2 & 5.9 & 19.7 & 25.1 & 2.7 & 3.7 & 3.4 & 1.9 & 9.9 & 13.1 \\
\hline Total & 23.6 & 19.5 & 9.9 & 17.5 & 5.4 & 5.2 & 2.4 & 2.6 & 17.7 & 16.7 & 25.9 & 22.2 & 3.4 & 4.5 & 2.7 & 4.0 & 8.0 & $\square .0$ \\
\hline
\end{tabular}

Source: Authors' estimations based on Narayanan et al. (2015) and in IMF (2015) for the projections. 
Table 5. Regions' shares in EU bilateral trade in 2020.

\begin{tabular}{|c|c|c|c|c|c|c|c|c|c|c|c|c|c|c|c|c|c|c|}
\hline & \multicolumn{2}{|c|}{ US } & \multicolumn{2}{|c|}{ China } & \multicolumn{2}{|c|}{ Japan } & \multicolumn{2}{|c|}{ India } & \multicolumn{2}{|c|}{ Latin America } & \multicolumn{2}{|c|}{ Other advanced } & \multicolumn{2}{|c|}{ Southeast Asia } & \multicolumn{2}{|c|}{ Sub-Saharan A. } & \multicolumn{2}{|c|}{ Middle-East } \\
\hline & Exports & Imports & Exports & Imports & Exports & Imports & Exports & Imports & Exports & Imports & Exports & Imports & Exports & Imports & Exports & Imports & Exports & nports \\
\hline 1.Agriculture & 5.0 & 9.6 & 8.6 & 4.4 & 1.4 & 0.1 & 0.9 & 3.0 & 2.9 & 33.2 & 19.9 & $\square 12.7$ & 1.4 & 5.6 & 8.9 & $\square 15.6$ & 50.9 & 15.9 \\
\hline 2.Other primary & 4.1 & 1.4 & $\square 11.5$ & 0.2 & 0.4 & 0.0 & 42.4 & 0.2 & 2.8 & 6.1 & $\square 16.9$ & 18.1 & 2.1 & 0.4 & 6.4 & 10.4 & 13.3 & 63.1 \\
\hline 3.Food & 16.4 & 8.6 & 5.6 & 7.3 & 4.9 & 0.3 & 0.7 & 2.6 & 5.2 & 27.4 & 24.6 & 21.1 & 3.7 & $\square 13.3$ & 9.2 & 8.3 & 29.6 & 10.9 \\
\hline 4.Textiles & 12.8 & 1.7 & 9.0 & 41.7 & 1.4 & 0.5 & 1.6 & 8.5 & 4.5 & 1.7 & 29.2 & 6.0 & 2.9 & $\square 17.7$ & 3.0 & 1.3 & 32.8 & 20.9 \\
\hline 5.Wood and paper & 10.0 & $\square 14.0$ & $\square 10.3$ & 33.2 & 3.3 & 0.8 & 2.9 & 0.9 & 5.5 & 9.6 & 29.9 & 19.3 & 2.9 & 8.0 & 4.8 & .3 & 30.4 & 11.0 \\
\hline 6.Chemicals & 23.1 & 25.9 & 7.7 & 8.0 & 3.9 & 3.6 & 2.2 & 4.6 & 7.4 & 3.7 & 23.4 & 22.6 & 2.2 & 3.5 & 5.5 & 1.1 & 24.7 & 27.0 \\
\hline 7.Metals & 11.1 & $\square 12.9$ & $\square 13.7$ & $\square 14.4$ & 1.7 & 3.5 & 6.9 & 2.2 & 5.3 & 7.2 & 29.5 & 32.8 & 2.5 & 1.8 & 3.6 & 5.3 & 25.8 & 19.9 \\
\hline 8.Motor vehicles & $\square 16.1$ & $\square 15.4$ & 21.0 & 6.5 & 3.3 & 21.5 & 1.6 & 3.6 & 6.2 & 9.5 & $\square 18.7$ & $\square 16.6$ & 1.5 & 3.3 & 5.1 & 3.8 & 26.4 & 19.8 \\
\hline 9.Other transport & 22.5 & 40.9 & $\square 13.4$ & $\square 12.0$ & 1.6 & 5.4 & 2.6 & 1.1 & 8.4 & 4.1 & 20.3 & 28.9 & 6.3 & 2.8 & 4.4 & 0.9 & 20.4 & 3.9 \\
\hline 10.Electronics & 10.3 & 8.6 & $\square 12.0$ & 52.2 & 1.8 & 4.6 & 4.2 & 0.5 & 4.1 & 1.7 & 26.8 & 20.4 & 6.8 & 8.6 & 6.3 & 0.1 & 27.6 & 3.2 \\
\hline 11.Ot & $\square 15.4$ & 21.5 & 18.0 & 28.0 & 2.2 & 10.5 & 4.4 & 1.5 & 7.5 & 2.2 & 18.8 & 24.6 & 3.0 & 3.8 & 4.9 & 1.1 & 25.8 & 6.8 \\
\hline 12.Other $\mathrm{n}$ & 22.7 & $\square 14.1$ & 5.4 & 46.4 & 2.7 & 3.1 & 3.5 & 6.3 & 4.6 & 1 & 30.3 & $\square 14.8$ & 2.3 & 5.8 & 4.8 & 1.3 & 23.7 & 6.7 \\
\hline 13.Construction & 2.9 & 9.3 & 7.3 & 13.2 & 10.5 & 19.7 & 2.4 & 2.3 & 1.7 & 3.9 & 7.9 & 22.8 & 7.4 & 8.4 & 9.3 & .1 & 50.6 & 19.4 \\
\hline 14.Water Transpo & 1.5 & 2.4 & 0.3 & 2.0 & $\square 13.2$ & 4.9 & 7.6 & 2.9 & 13.3 & 19.8 & 48.3 & 32.5 & 5.3 & 12.4 & 2.7 & 3.4 & 7.8 & 19.7 \\
\hline 15.Air Transport & 23.7 & 24.2 & 3.5 & 2.9 & 4.3 & 4.1 & 6.0 & 0.8 & 9.9 & 6.6 & 26.9 & 23.2 & 5.5 & $\square 12.2$ & 6.3 & 4.9 & $\square 13.9$ & 21.1 \\
\hline 16.Communications & 23.7 & 23.3 & 1.4 & 2.6 & 2.7 & 0.7 & 3.4 & 3.6 & 8.2 & 9.1 & 23.4 & $\square 16.6$ & 7.9 & $\square 10.5$ & 6.2 & 4.3 & 23.1 & 29.2 \\
\hline 17.Finance & 37.7 & 46.5 & 1.8 & 0.5 & 3.9 & 2.7 & 5.9 & 2.1 & 5.1 & 2.9 & 23.4 & 35.3 & 3.0 & 1.7 & 2.4 & 1.2 & 16.8 & 7.0 \\
\hline 18.Insurance & 50.1 & 42.3 & 6.8 & 2.7 & 2.0 & 2.8 & 4.2 & 2.4 & 6.7 & 8.3 & $\square 10.7$ & 18.7 & 3.9 & 6.6 & 3.9 & 3.0 & $\square 11.7$ & 13.1 \\
\hline 19.Busines & $\square 13.9$ & 28.8 & 6.2 & 4.1 & 5.2 & 3. & 7.6 & 11.6 & 7.2 & 5.3 & 27.2 & 29.0 & 7.2 & 4.4 & 6.8 & 1.3 & 18.6 & 12.4 \\
\hline ervices & 15.6 & 32.4 & 2.5 & 4.6 & 4.0 & 1. & 2.6 & 1.1 & $\square 11.8$ & 10.0 & 26.7 & 22.7 & 8.3 & 10.6 & 5.2 & 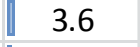 & 23.3 & 13.7 \\
\hline & 21.0 & 23.1 & $\square 10.8$ & 8.5 & 2. & 4 & 3. & 1.9 & 7.5 & 6.9 & 21.7 & 22.8 & 5. & 9.3 & 6.0 & 2.8 & 21.7 & 20.8 \\
\hline All & 16.7 & 13.6 & 13.0 & 18.5 & 3. & 4.2 & 3.8 & 2.6 & 6.4 & 5.1 & 22.6 & 20.7 & 0 & 4.9 & 5.3 & 3.9 & 26.2 & 26.4 \\
\hline All services & 21.6 & 27.8 & $\square 6.3$ & 4.9 & 4.3 & 3.4 & 5.3 & 5.0 & $\square 7.9$ & $\square 6.7$ & 24.9 & 26.1 & 5.9 & $\square 7.4$ & 5.6 & 2.5 & 18.2 & 16.4 \\
\hline Total & 17.8 & 16.7 & 11.3 & 15.1 & 3.3 & 3.9 & 4.1 & 3.2 & $\square 6.8$ & $\square 6.2$ & 23.2 & 21.8 & 3.7 & $\square .5$ & 5.4 & 3.9 & 24.5 & 23.8 \\
\hline
\end{tabular}

Source: Authors' estimations based on Narayanan et al. (2015) and in IMF (2015) for the projections. 
Our microeconomic results will concentrate on the strongest possible impact of the agreement which arises in the long term ${ }^{10}$ with an ambitious TTIP, simultaneously including the three elements we have just described. This scenario (a standard ambitious or deep TTIP scenario) in which the effects for outsiders would be the most intense, therefore, offers an upper bound estimate on the negative effects for third countries. For the macroeconomic outcomes, we present the long run effects of both a modest and ambitious TTIP, to be able to compare them. A final comment about the recent British referendum held on June 23, 2016 in favor of Brexit seems in order. This outcome is another force operating in the economies that could potentially make the impact of TTIP more limited, insofar as it reduces the size of the EU area and its weight in world trade. Much uncertainty surrounds the future of UK foreign relationships in this moment. However, as long as the UK continues to have a very open trade and FDI regime with both of the TTIP areas, the outcomes for outsiders of a TTIP agreement are likely to be similar to the ones derived in this paper.

\section{Results}

\section{Sectoral results}

Table 6 presents the impact on output (left), exports (center) and imports (right) for all sectors (rows) and regions (columns), including the total world economy. All the results should be viewed as annual percentage changes several years after an ambitious agreement and due solely to the impact of the TTIP ${ }^{11}$. We estimate the "total" impact of the "standard TTIP", which includes the effects of the three components (NTBs, tariffs and FDI) we have just described in the previous section.

Beginning with output there is an expansionary trend, which is similar in the EU and in the US (with an overall rise of $0.69 \%$ and $0.67 \%$, respectively). The increase is larger, however, in European manufactures $(0.73 \%)$ than in US manufactures $(0.45 \%)$.

The sectors that grow more in the EU are insurance, motor vehicles, textiles, food, finance and chemicals (in that order). All these sectors experience sizeable expansions in their exports in many cases coupled with less intense increase in imports. In general, the evolution of exports and imports of a particular sector can be understood by looking at the level of its $\mathrm{NTBs}^{12}$ and to the share of the other TTIP partner in trade within that sector. European exports grow more in sectors like other primary ${ }^{13}$, insurance, food, textiles, finance, insurance, chemicals, other transport and motor vehicles (in that order). This can be explained by both the large pre-existing NTBs in the US (Table 1), coupled with a sizeable US share in exports of these sectors (Table 5). In the case of textiles, the elimination of the high US tariff accounts for an important part of its evolution.

With respect to EU imports, the largest increases are experienced in food and motor vehicles, which exhibit a combination of high NTBs and tariffs in the EU, as well as an important US share in European imports. The rise in exports will tend to increase production while tougher competition from imports may reduce it. While an expansionary trend prevails also in US manufacturing $(0.45 \%)$ a few sectors reduce their output. Note that in general the rise in exports of manufacturing surpasses by far the increase in imports $(6.97 \%$ versus $4.52 \%)$. In line with our previous findings, the growth in exports is stronger in the sectors which exhibit relatively large European NTBs and European bilateral shares in US exports. These are the case of other primary, other transport, communication, finance and business services. The European tariff in food, textiles and motor vehicles increase even more the already sizeable barriers to trade related to NTBs in

\footnotetext{
${ }^{10}$ The short term impact arises from the static version of the model and is also weaker than the long run impact that is derived from its steady state version. While capital endowment is exogenous in the static version, capital return is exogenous with endogenous capital endowment in the steady state version.

${ }^{11}$ Our model isolates the impact of the agreement, while in the real world, of course, other forces would be interacting simultaneously with it.

${ }^{12}$ As we saw in Table 1, the largest costs savings are related, in general, with NTBs. However, for the few sectors in which tariffs are high, such as food, textiles and motor vehicles, tariffs also play a role.

${ }^{13}$ The strong increase in exports of other primary is related to the very low initial level of EU exports.
} 
Table 6. Long term impact on Output, Exports and Imports of an ambitious TTIP agreement (\% changes with respect to the initial data)

Ouput

Exports

Imports EUR USA CHN JPN IND LAC OAC SEA SSA MEN World EUR USA CHN JPN IND LAC OAC SEA SSA MEN EUR USA CHN JPN IND LAC OAC SEA SSA MEN World

1.Agriculture 2.Other primary

3.Food

4.Textiles

5.Wood and paper

6.Chemicals

7.Metals

8.Motor vehicles

9.Other transport

10.Electronics

11.Other machinery

12.Other manufactures
13.Construction

14.Water Transport

15.Air Transport

16.Communications

17.Finance

18.Insurance

19.Business services

20.Personal services

21.Other services

All manufactures

All servives

total
EUR USA CHN JPN IND LAC OAC SEA SSA MEN Wo

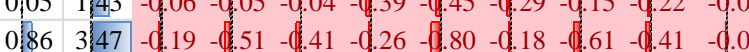

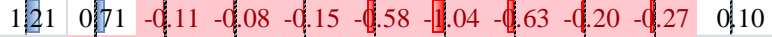

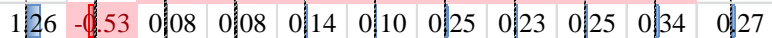

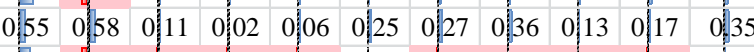
$\begin{array}{llllllllllllll}0.92 & -0.48 & -0.11 & -0.15 & -0.13 & 0.02 & -0.12 & -0.04 & -0.01 & -0.08 & 0.06\end{array}$

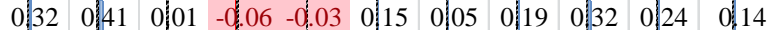
$1.35-0.73-0.09-0.35-0.13-0.19-0.33-0.08-0.07-0.07 \quad 0.14$

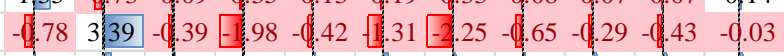
0,08 0,5

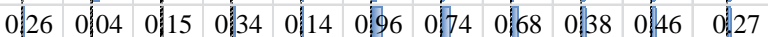

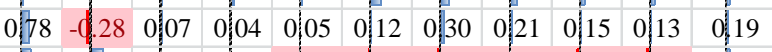
$\begin{array}{lllllllllll}0,80 & 1,04 & 0.00 & 0.00 & -0.01 & -0.15 & -0.17 & -0.05 & -0.23 & -0.21 & 0.27\end{array}$

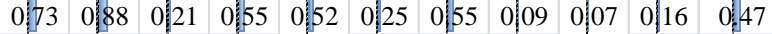

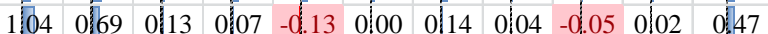

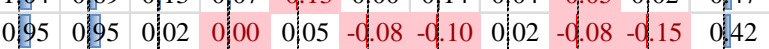
$\begin{array}{llllllllllll}1,16 & 0,78 & 0.01 & 0.02 & 0.02 & -0.08 & -0.06 & -0.01 & -0.16 & -0.16 & 0.49\end{array}$

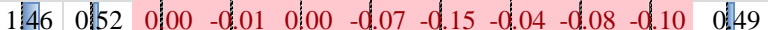

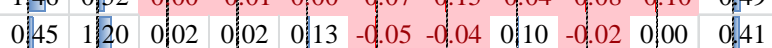

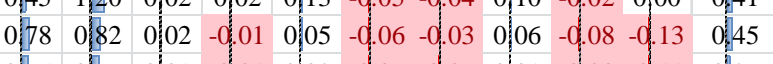
$\begin{array}{lllllllllllllll}0.65 & 0.69 & 0.01 & -0.01 & 0.02 & -0.07 & -0.06 & 0.01 & -0.03 & -0.11 & 0.29\end{array}$ $\begin{array}{llllllllllllll}0.73 & 0.45 & 0.00 & -0.06 & -0.05 & -0.07 & -0.13 & -0.03 & -0.14 & -0.14 & 0.16\end{array}$

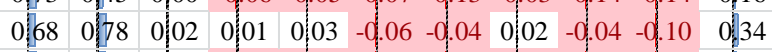

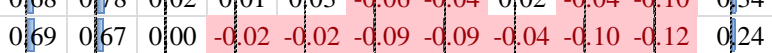
\begin{tabular}{l|l|l|l|l|l|l|l|l|l|l|l|l|l|l|l|l|l|l|l|l|}
4.34 & 5.03 & -0.89 & -0.69 & -0.73 & -0.53 & -0.36 & -0.09 & -0.44 & -0.53 & 8.08 & 2.54 & -0.03 & -0.06 & 0.10 & -1.06 & -0.78 & -0.57 & -0.56 & 0.61 & 1.27 \\
\hline
\end{tabular} \begin{tabular}{l|l|l|l|l|l|l|l|l|l|l|l|l|l|l|l|l|l|l|l|l|l|l}
19.13 & 66.36 & -1.33 & -0.90 & -0.74 & -0.60 & -1.30 & -0.30 & -0.72 & -0.68 & 1.15 & 0.45 & 0.12 & -0.12 & -0.04 & -0.41 & -0.08 & 0.13 & -0.01 & -0.79 & 0.31 \\
\hline
\end{tabular}

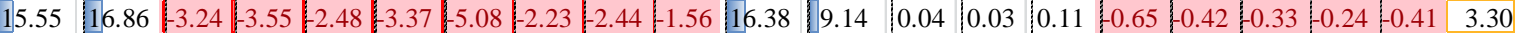
\begin{tabular}{|l|l|l|l|l|l|l|l|l|l|l|l|l|l|l|l|l|l|l|l|l|l|}
12.00 & 15.71 & 0.12 & 0.07 & 0.40 & -0.27 & 0.20 & 0.30 & 1.18 & 1.43 & 4.52 & 5.17 & -0.20 & -0.05 & -0.13 & -0.70 & -0.35 & 0.02 & -0.47 & -0.55 & 1.92 \\
\hline
\end{tabular} \begin{tabular}{l|l|l|l|l|l|l|l|l|l|l|l|l|l|l|l|l|l|l|l|l|}
0.50 & 0.56 & 0.55 & 0.26 & 0.39 & 1.29 & 0.96 & 0.82 & 1.19 & 1.19 & 3.60 & 2.10 & -0.08 & -0.02 & -0.10 & -0.88 & -0.42 & -0.17 & -0.41 & -0.51 & 0.70 \\
\hline
\end{tabular}

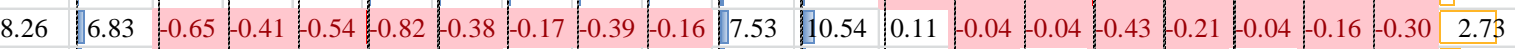

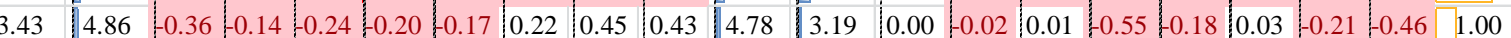

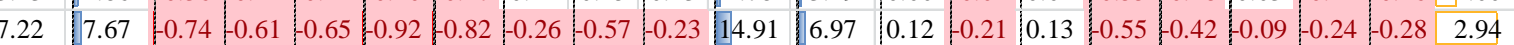

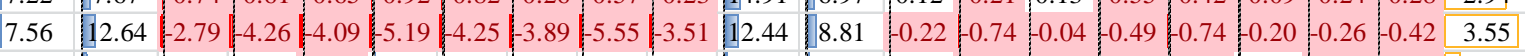
\begin{tabular}{|l|l|l|l|l|l|l|l|l|l|l|l|l|l|l|l|l|l|l|l|l|}
3.42 & 4.90 & 0.12 & 0.09 & -0.09 & 0.91 & 0.29 & 0.24 & 0.48 & 0.40 & 2.64 & 1.84 & 0.08 & -0.02 & -0.03 & -0.19 & -0.06 & 0.11 & -0.39 & -0.48 & 0.79
\end{tabular} \begin{tabular}{|l|l|l|l|l|l|l|l|l|l|l|l|l|l|l|l|l|l|l|l|l|l|}
\hline 0.41 & -0.23 & 0.67 & 0.50 & 0.64 & 1.49 & 0.90 & 0.96 & 1.61 & 1.63 & 2.89 & 2.21 & -0.13 & -0.04 & -0.15 & -0.40 & -0.25 & 0.04 & -0.42 & -0.51 & 0.56 \\
\hline
\end{tabular}

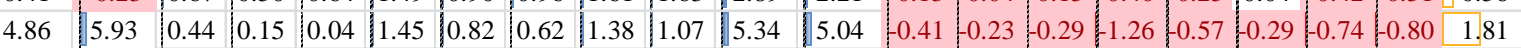

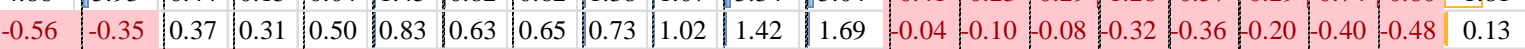
\begin{tabular}{l|l|l|l|l|l|l|l|l|l|l|l|l|l|l|l|l|l|l|l|l|l|l|l|l}
0.29 & 0.09 & -0.12 & -0.12 & -0.05 & 0.30 & 0.22 & 0.16 & 0.25 & 0.31 & 0.21 & 1.86 & 0.18 & 0.38 & 0.17 & 0.00 & 0.21 & 0.05 & -0.02 & -0.20 & 0.23 \\
\hline
\end{tabular} \begin{tabular}{|l|l|l|l|l|l|l|l|l|l|l|l|l|l|l|l|l|l|l|l|l|l|l|}
2.06 & 2.51 & -0.26 & -0.31 & -0.25 & 0.09 & 0.02 & -0.04 & 0.06 & 0.12 & 1.40 & 3.31 & 0.31 & 0.22 & 0.33 & 0.08 & 0.15 & 0.25 & 0.09 & -0.07 & 1.04 \\
\hline
\end{tabular}

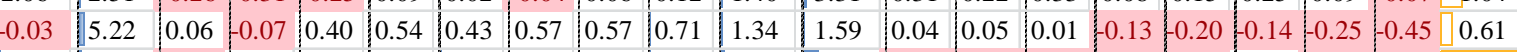
\begin{tabular}{|l|l|l|l|l|l|l|l|l|l|l|l|l|l|l|l|l|l|l|l|l|}
\hline 10.19 & 3.71 & -0.14 & 0.50 & 0.36 & 0.49 & 0.73 & 0.47 & 0.45 & 0.73 & 3.20 & 14.59 & -0.09 & -0.38 & -0.11 & -0.16 & -0.40 & 0.08 & -0.19 & -0.51 & 4.04 \\
\hline
\end{tabular}

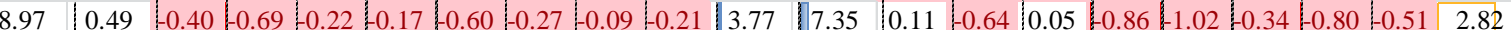

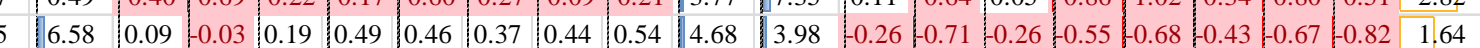

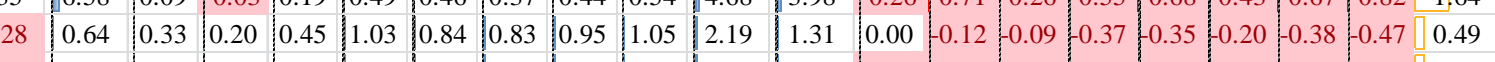
\begin{tabular}{l|l|l|l|l|l|l|l|l|l|l|l|l|l|l|l|l|l|l|l|l}
-0.06 & 0.05 & 0.41 & 0.30 & 0.44 & 1.01 & 0.81 & 0.78 & 0.96 & 1.08 & 1.70 & 1.47 & -0.02 & -0.10 & -0.15 & -0.41 & -0.44 & -0.23 & -0.36 & -0.55 & 0.45 \\
\hline
\end{tabular} \begin{tabular}{|l|l|l|l|l|l|l|l|l|l|l|l|l|l|l|l|l|l|l|l|l|l|l|l|}
\hline & 6.97 & -0.01 & -0.15 & -0.41 & -0.61 & -0.42 & -0.14 & -0.48 & -0.40 & 5.03 & 4.52 & 0.03 & -0.08 & -0.05 & -0.48 & -0.25 & -0.01 & -0.29 & -0.45 & 1.48
\end{tabular}

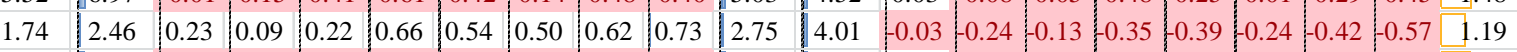

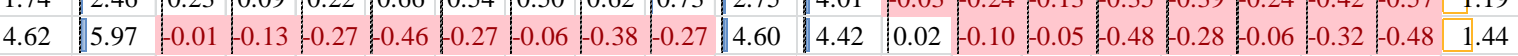

Source: Authors’ estimations.

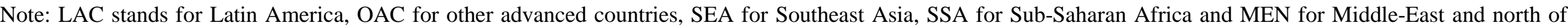
Africa. 
these sectors. When the former are eliminated and the latter are reduced, the US increases considerably exports in these sectors.

On the import side, food, other transport, finance and insurance combine big EU shares with rather large NTBs in the US. This fact underlies their remarkable increase across US imports. Imports of chemicals and motor vehicles also rise intensively. This explains why even though they exhibit important increases in exports, they will end up reducing production.

Protection is higher in the barriers to FDI in the US compared to the one in the EU (Table 1). This is particularly clear in the sector of business services, which accounts for a very sizeable share in overall services. When this protection is lowered, production increases in the US, since productive capital (namely, FDI) can be installed there more easily. That is why overall production in services in the US grows more than in the EU (0.78\% versus $0.68 \%$, respectively). Let us turn now to the impact for "outsiders". We can see that across manufacturing there are reductions in exports in many sectors for all areas outside the TTIP. Indeed exports of "all manufactures" always fall for outsiders, although with different intensity. This outcome, is in turn, reflected in output which tends to follow the trend of exports (i.e., production experiences decreases or increases in the sectors in which exports go up or down, respectively).

By contrast, the general pattern of exports from services is of increase. This is also shown in the expanding evolution of exports of "all services", although production in these sectors is less related to exports than in the manufacturing case. Put differently, in services, the amount of production devoted to exports is smaller and accordingly the push for production of exports is less important.

The pattern of exports followed by outsiders that we have just explained reflects the intensity of the resulting trade integration between Europe and the US after the TTIP. In order to show this, Table 7 offers the impact of bilateral imports among the regions considered. The first part (on the left) presents EU imports in the different sectors coming from the areas that appear in the columns. The second part (on the right) offers the same results for US imports. EU total bilateral imports coming from the US grow by $31.1 \%$ mostly driven by "all manufactures" with an increase of $42 \%$, while the increase in "all services" is of $8.4 \%$. On the other hand, "total" US bilateral imports coming from the EU increase by $28.8 \%$. Again, manufacturing accounts for the bulk of the increase (35.9\%), while services imports increase by $9.8 \%$.

Table 7 reflects that with the reduction in costs that the TTIP implies, the EU and US increase their bilateral imports very heavily across all sectors. Imports from the rest of regions tend to exhibit two contrasting patterns. Imports coming from areas outside the TTIP in manufacturing tend to decrease (with a few exceptions), while in services they tend to increase although very slightly. The decrease in manufacturing must be related to the fact that cost savings from the TTIP are larger in manufacturing (which exhibit higher NTBs than services and additionally have tariffs, which are absent in services sectors). As a consequence, after the agreement imports coming from the partner at the other side of the Atlantic become considerably cheaper compared to imports from other areas of the world. This results in very important increases in imports from the TTIP partner and reductions in imports from the rest of sources, which is known as trade diversion. By contrast, cost savings are more limited in services, and the bilateral increases in imports between the TTIP partners are less intense in these sectors than in manufacturing. Thus, the trade diversion is small in services. There is even room for increases in services coming from areas outside the TTIP because the increased manufacturing production in the US and the EU leads to the larger demand of services, which results in the positive impact of their import even from the outsiders. Such positive impact on the import from outsiders could dominate the negative impact from the trade diversion.

There are a few manufacturing sectors with an exceptional trend in which bilateral imports from areas outside the TTIP also increase. This pattern appears for European imports in textiles, wood and paper, other machinery, other manufacturing and for a few regions in electronics. In the case of imports going to the US the pattern also appears in the same sectors, excluding textiles. A closer look at the bilateral imports between the transatlantic areas in these few sectors reveals that their increases in bilateral imports are weaker than in the rest of manufacturing sectors. Indeed, if we look at the levels of existing NTBs and tariffs we find they are among the ones that are less "protected" (i.e., the cost savings related to both NTBs and tariffs are smaller). The extreme case would be other machinery, in which there are no NTBs at all and the tariffs are minimal. Because the initial barriers are so small, then, the TTIP would not make 
firms save many costs. That is why the increase in bilateral imports between the TTIP partners in these sectors is less intense than in the rest of manufacturing sectors. There is even scope for imports from other areas, similarly to what happened in services.

The contrasts in the evolution of bilateral imports shown in Table 7 turn out to be very important for the evolution of total (not bilateral) sectoral exports from Table 6. If we go back to this latter table again, we can see that across manufacturing "outsiders" increase exports precisely in the sectors in which the integration between the EU and US is not particularly strong, due to the smaller savings in costs. As mentioned above, the evolution of production of the "outsiders" seems to be quite related with their export performance. In other words, those sectors and areas outside the TTIP exporting more are the ones that tend to increase production. Although, this pattern is quite clear for manufacturing and less clear for services sectors, due to their weaker orientation to trade and the more important role of FDI in services.

Looking at the overall evolution of production (row "total" in Table 6) we find a slightly negative effect for the Middle-East region (-0.12\%), followed by Sub-Saharan Africa (-0.10\%) and other advanced and Latin America (both with $-0.09 \%$ ). The negative results would be much smaller for South East Asia (0.04\%) and even negligible for India and Japan (both with $-0.02 \%$ ). They would be absent for China, whose output remains unaffected $(0.0 \%)$.

This differential impact on overall production across outsiders is the result of the interaction of several sources. On the one hand, manufacturing production tends to be quite related to exports. Exports, in turn, will tend to increase (decrease) when the export structure of the different areas is specialized in sectors in which the TTIP partners trade less (more) intensively. Chinese exports remain nearly constant in manufacturing $(-0.1 \%)$. This is because, among the regions considered, its export basket is the most specialized in the sectors that increase exports to the TTIP area $\left(68.8 \%\right.$ of its exports $\left.{ }^{14}\right)$. On the opposite extreme, the Middle-East and Sub-Saharan Africa region exhibit the lowest shares of exports in the expanding sectors (6.1\% and 3.7\%, respectively). In addition, these two regions also suffer from their strong specialization in exports of other primary, as well as agriculture and food. In the latter three sectors, the TTIP area becomes heavily integrated reducing exports coming from other regions. This explains why these two areas (Middle-East and Sub-Saharan Africa) suffer relatively larger overall output reductions compared to the rest of regions of $-0.12 \%$ and $-0.10 \%$, respectively.

Other advanced countries are the area that is most integrated with both of the TTIP partners, as we saw in Tables 4 and 5. In manufacturing its exports will decrease because it is not specialized in the sectors that increase their exports to the TTIP. Those sectors account only for $31.8 \%$ of its overall exports. Other advanced countries increase services exports but this will not bring about an increase in production in them. This is because, services' production is less oriented to trade (than the one of manufacturing) and they suffer, instead, from the contraction in manufacturing production. In other words, production in services of this area will go down, because downstream sectors (i.e., manufacturing sectors) are reducing production, dragging down production in services sectors ${ }^{15}$

\footnotetext{
${ }^{14}$ The reader can check in Table 3 that the sum of the shares in overall Chinese exports of the sectors textiles, wood, electronics, other machinery and other manufacturing adds up to 68.8\% (and to the percentages that will be quoted below for other areas). Recall that these sectors were the ones in which outsiders increased exports to the TTIP area, due to weaker trade integration of the TTIP partners in them.

${ }^{15}$ The sectors of other services and, to a lesser extent, business services are much more oriented to the provision of intermediates for other sectors than to exports. Since these two sectors account for the bulk of services production, the latter will be very responsive to the negative evolution of manufacturing sectors. The percentage of production in other services devoted to intermediates going to manufacturing sectors versus the one exported are, respectively, as follows: EU (8.4 vs. 4.3), US (9.3 vs. 1.3), China (29.2 vs. 1.1), Japan (12.3 vs. 0.8), India (21.3 vs. 1.0), Latin America (13.9 vs. 1.4), other advanced (12.0 vs. 3.9), Southeast Asia (20 vs 4.3), Sub-Saharan Africa (25.2 vs. 2.3), Middle-East (18.4 vs. 3.0). For the sector of business services the same percentages are EU (24.3 vs. 12.0), US (16.7 vs. 4.9), China (34.3 vs. 2.4), Japan (20.6 vs. 1.8), Latin America (23.1 vs. 4.5), other advanced (19.0 vs. 10.9 ), Southeast Asia (18.4 vs 15.2), Sub-Saharan Africa (19.8 vs. 3.6), Middle-East (23.5 vs. 11.1). Only India exhibits an exceptional trade in business services with percentages of (12.3 vs. 30.3). We have omitted the percentages of intermediates going to other services sectors, which would dwarf even more the importance of exports as a destination of production in services sectors.
} 
Table 7. Long term impact on bilateral imports in the EU and in the US of an ambitious TTIP agreement (\% changes with respect to the initial data)

\begin{tabular}{|c|c|c|c|c|c|c|c|c|c|c|c|c|c|c|c|c|c|c|}
\hline & \multicolumn{9}{|c|}{ EU bilateral imports } & \multicolumn{9}{|c|}{ US bilateral imports } \\
\hline & US & CHN & JPN & IND & LAC & OAC & SEA & SSA & MEN & EU & CHN & JPN & IND & LAC & OAC & SEA & SSA & MEN \\
\hline 1.Agriculture & 98.2 & -1.9 & -2.0 & -1.9 & -1.3 & -1.5 & -1.3 & -1.3 & -1.3 & 108.6 & -2.5 & -2.5 & -2.4 & -1.9 & -2.1 & -1.8 & -1.8 & -1.8 \\
\hline 2.Other primary & 291.4 & -3.8 & -3.9 & -3.8 & -3.0 & -3.3 & -3.4 & -3.0 & -2.9 & 504.9 & -2.0 & -2.1 & -1.9 & -1.1 & -1.5 & -1.5 & -1.2 & -1.1 \\
\hline 3.Food & 211.3 & -2.3 & -2.4 & -2.3 & -1.7 & -2.0 & -1.9 & -1.7 & -1.8 & 97.8 & -16.9 & -17.0 & -16.9 & -16.5 & -16.7 & -16.6 & -16.5 & -16.5 \\
\hline 4.Textiles & 126.6 & 2.4 & 2.4 & 2.4 & 3.3 & 2.5 & 2.5 & 3.0 & 2.6 & 111.8 & -2.0 & -2.1 & -2.0 & -1.2 & -1.9 & -1.9 & -1.5 & -1.8 \\
\hline 5.Wood and paper & 17.4 & 1.1 & 1.1 & 1.2 & 1.8 & 1.5 & 1.5 & 1.7 & 1.7 & 11.8 & 0.8 & 0.8 & 0.9 & 1.5 & 1.2 & 1.3 & 1.5 & 1.4 \\
\hline 6.Chemicals & 31.2 & -1.0 & -1.0 & -0.9 & -0.6 & -0.7 & -0.7 & -0.6 & -0.6 & 36.2 & -1.9 & -1.8 & -1.8 & -1.4 & -1.6 & -1.6 & -1.5 & -1.4 \\
\hline 7.Metals & 35.3 & -0.1 & -0.1 & 0.0 & 0.6 & 0.3 & 0.3 & 0.6 & 0.6 & 38.1 & -2.8 & -2.9 & -2.8 & -2.2 & -2.5 & -2.5 & -2.2 & -2.2 \\
\hline 8.Motor vehicles & 99.6 & -0.7 & -0.6 & -0.7 & -0.2 & -0.4 & -0.5 & -0.3 & -0.2 & 45.0 & -1.8 & -1.7 & -1.8 & -1.3 & -1.5 & -1.6 & -1.4 & -1.3 \\
\hline Other transport & 42.4 & -8.6 & -8.7 & -8.5 & -7.9 & -8.3 & -8.2 & -7.9 & -7.8 & 32.4 & -10.5 & -10.6 & -10.4 & -9.8 & -10.2 & -10.1 & -9.8 & -9.7 \\
\hline 10.Electronics & 34.1 & -0.4 & -0.4 & -0.3 & 0.0 & -0.2 & -0.2 & 0.3 & 0.3 & 38.4 & 0.7 & 0.7 & 0.8 & 1.1 & 0.9 & 0.9 & 1.4 & 1.4 \\
\hline 11.Other machinery & 8.9 & 1.1 & 1.0 & 1.1 & 1.8 & 1.4 & 1.4 & 1.8 & 1.9 & 6.7 & 0.8 & 0.7 & 0.8 & 1.5 & 1.1 & 1.1 & 1.5 & 1.6 \\
\hline 12.Other manufactures & 29.6 & 1.2 & 1.2 & 1.3 & 2.0 & 1.5 & 1.5 & 1.9 & 1. & 25.7 & 0.9 & 0.9 & 1.0 & 1.6 & 1.2 & 1.2 & 1.6 & 1.6 \\
\hline 13.Construction & 3.3 & 1.1 & 1.0 & 1.1 & & 1 & & 1. & & 2.8 & 1. & 1. & 1.4 & 1. & 1.6 & 1.6 & 1.7 & 1.7 \\
\hline 14.Water Transport & 6.9 & 0.0 & 0.0 & 0.1 & & 0.2 & & & & 10.1 & 0.2 & 0.2 & 0.2 & $\theta$ & 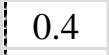 & 0.4 & 0.5 & 0.5 \\
\hline 15.Air Transport & 5.9 & -0.2 & -0.2 & -0.2 & 0.1 & 0.0 & 0.0 & 0.1 & 0.1 & 7.5 & 0.0 & -0.1 & 0.0 & 0.3 & 0.2 & 0.2 & 0.3 & 0.3 \\
\hline 16.Communications & 7.8 & 0.5 & 0.5 & 0.6 & 0.9 & 0.8 & 0.8 & 0.9 & 0.9 & 2.3 & 1.2 & 1.1 & 1.2 & & & 1.4 & 1.5 & 1.5 \\
\hline 17.Finance & 6.6 & 0.6 & 0.5 & 0.6 & 1.0 & 0.8 & 0.8 & 0.9 & 1.0 & 23.1 & 1.3 & 1.2 & 1.3 & 1.7 & 1.5 & 1.5 & 1.6 & 1.7 \\
\hline 18.Insurance & 7.9 & 0.1 & 0.1 & 0.1 & 0 . & 0. & 0. & 0 . & 0 . & 14.1 & -1.8 & -1.9 & -1.8 & -1.4 & -1.6 & -1.6 & -1.5 & -1.4 \\
\hline 19.Business services & 16.2 & 0.5 & 0.4 & 0.5 & 0. & 0.7 & 0. & 0 . & 0 . & 13.3 & 0. & 0 . & 0.3 & 0.6 & 0.5 & 0.5 & 0.6 & 0.6 \\
\hline 20.Personal services & 3.9 & 1.1 & 1.0 & 1.1 & 1.0 & 1.4 & 1.4 & 1. & 1. & 2.1 & 0.0 & 0.7 & 0.8 & 1.3 & 1. & 1.0 & 1.3 & 1.2 \\
\hline 21.Other services & 3.2 & 1.0 & 0.9 & 1.0 & 1.5 & 1.3 & 1.2 & 1.5 & 1.5 & 2.4 & 0.9 & 0.9 & 1.0 & 1.5 & 1.3 & 1.2 & 1.4 & 1.4 \\
\hline All manufactures & 42.0 & 0.4 & -0.3 & 0.2 & -1.1 & -1.0 & 0.5 & -1.8 & -1.5 & 35.9 & -0.4 & -1.2 & -2.2 & -1.3 & -1.8 & -2.3 & -1.3 & -1.3 \\
\hline All services & 8.4 & 0.7 & 0.6 & 0.5 & 1.0 & 0.8 & 0.8 & 1.0 & 1.0 & 9.8 & 0.6 & 0.4 & 0.4 & 1.0 & 0.7 & 0.7 & 1.0 & 0.9 \\
\hline Total & 31.1 & 0.4 & -0.2 & 0.3 & -0.6 & -0.5 & 0.5 & -1.4 & -1.1 & 28.8 & -0.4 & -1.0 & -1.2 & -1.3 & -1.4 & -1.9 & -1.2 & -0.9 \\
\hline
\end{tabular}

Source: Authors' estimations.

Note: See note in Table 6. 
In Latin America the share of the sectors whose exports expand to the TTIP area is quite reduced (19.4\% of total exports). As a result, there is a decrease of its manufacturing exports. This will, in turn, contract manufacturing output, which will also bring about a fall in services production due to their already mentioned input-output connections.

In general, we can see that manufacturing exports also fall in the rest of regions, which are concentrated in Asia, such as India, Japan and South East Asia. The decrease in exports from regions of Asia (including China) tends to be of smaller magnitude than in the regions outside Asia (i.e., other advanced economies, Latin America, Middle East and Sub-Saharan region). For Japan and South East Asia the weight in trade of the sectors expanding their exports to the TTIP is relatively high (44.4\% and 36.9\% of overall exports, respectively). It is smaller in India (29.3\%), which explains why exports in manufacturing fall by more in this region. Another force reducing the negative impact for manufacturing exports in Asia would be their weaker integration with the TTIP area (with the exception of China), compared to other advanced economies, to the Middle East or to Latin America, as we saw in the regions' shares of Tables 4 and 5. Because the fall in exports in manufacturing is milder, so is the reduction in production. This also has the positive consequence that services production does not go down in this region. Overall output reductions are tiny for the Asiatic regions.

What is the impact of all these forces on the world economy? The last column of Table 6 offers the percentage evolution of total world exports (and imports, which necessarily coincide). Recall exports of outsiders tended to decrease (grow) in those sectors in which trade integration between the EU and US was (not) very intense. Due to these compensating forces across regions, world trade in manufactures rises by $1.48 \%$. The figure is similar to the increase in world trade services $(1.19 \%)$, which underlies the milder trade adjustments in services across regions. Since manufactures account for the bulk of trade flows, the overall impact on the latter is $1.44 \%{ }^{16}$. This would yield a world output growth of $0.24 \%$.

\section{Aggregate outcomes}

Table 8 displays the evolution of five blocks of long run results on GDP, welfare (measured as is standard in equivalent variation ${ }^{17}$ ), wages and aggregate imports and exports for the different regions. On its left appear the results for the ambitious scenario, while on the right they are for a modest scenario. Thus, we can now compare the impact of 25\% (ambitious) cost reductions and 10\% (modest) cost reductions presented in Table 1. In both cases and for each block of results the rows of "Standard TTIP" cover the total impact whose outcomes have just been analyzed at the microeconomic level. The next rows present the isolated impact of the three main components of that total (namely, NTBs, tariffs and FDI). In the rows below the "inclusive TTIP" appears together with its two components ("direct spillovers" and "indirect spillovers"), which will be explained shortly.

A quick comparison between the right and the left part of this table shows that for the TTIP to have a certain impact on outsiders the agreement would need to be an ambitious one. With a modest TTIP the effects for outsiders are negligible. Another important set of results from this table emanates precisely from the "total" impact of the "standard TTIP" in the ambitious scenario. The evolution of the "total" production we have derived across the different areas (last row at the right part of Table 6) runs parallel to the GDP outcomes we now see in Table 8. This implies that the findings again show that the impact is only slightly negative for some outsiders. Such negative impact is absent in China and negligible in India and Japan, with GDP remaining nearly unaffected in these Asiatic regions. By contrast, the somewhat larger falls in GDP take place in Middle-East (-0.20\%), SubSaharan Africa (-0.14\%), followed by Other advanced economies (-0.12\%), Latin America (-0.09\%) and South East Asia (-0.05\%), which are the regions experiencing relatively larger output contractions order).

\footnotetext{
${ }^{16}$ To put this figure in perspective, we have calculated that during the period 2005-2015 world trade has risen annually by a simple (not cumulative) rate of $5.9 \%$, according to the series in the World Development Indicators from the World Bank. The $1.44 \%$ growth stemming from the TTIP would be very similar to the increase in 2014 (1.40\%) before it plummeted by $-10.47 \%$ in 2015.

${ }^{17}$ Welfare is measured as Hicksian equivalent variations of consumption, i.e., as a proxy for the increase in national income brought about by the shock (for more details see Burfisher, 2011).
} 
Table 8. Long term impact on GDP, Welfare and Wages of an ambitious and a modest TTIP agreement (\% changes with respect to the initial data)

\begin{tabular}{|c|c|c|c|c|c|c|c|c|c|c|c|c|c|c|c|c|c|c|c|c|c|c|}
\hline & \multicolumn{11}{|c|}{ Ambitious } & \multicolumn{11}{|c|}{ Modest } \\
\hline & \multicolumn{22}{|c|}{ GDP } \\
\hline & EUR & USA & CHN & JPN & IND & LAC & OAC & SEA & SSA & MEN & World & EUR & USA & CHN & JPN & IND & LAC & OAC & SEA & SSA & MEN & World \\
\hline Standard TTIP & 0.82 & 0.82 & 0.00 & -0.01 & 0.00 & -0.09 & [ -0.12 & -0.05 & -0.14 & -0.20 & 0.31 & 0.34 & 0.33 & 0.00 & $\mid-0.01$ & \begin{tabular}{|l|}
0.00 \\
\end{tabular} & -0.03 & -0.04 & -0.02 & -0.03 & {$[-0.05$} & 0.13 \\
\hline NTBs & 0.48 & 0.36 & 0.01 & 0.00 & 0.00 & -0.09 & -0.10 & -0.04 & -0.16 & -0.21 & 0.14 & 0.17 & 0.12 & 0.00 & 0.00 & \begin{tabular}{|l|}
0.00 \\
\end{tabular} & -0.03 & -0.03 & -0.01 & -0.04 & -0.05 & 0.05 \\
\hline Tariffs & 0.07 & 0.07 & -0.01 & -0.01 & 0.00 & -0.01 & -0.01 & -0.01 & 0.01 & 0.00 & 0.03 & 0.07 & 0.07 & -0.01 & $\mid-0.01$ & $\begin{array}{l}0.00 \\
\end{array}$ & -0.01 & -0.01 & -0.01 & 0.01 & 0.00 & 0.03 \\
\hline FDI & 0.25 & 0.37 & 0.00 & 0.00 & -0.01 & 0.00 & 0.00 & 0.00 & 0.01 & 0.01 & 0.13 & 0.09 & 0.13 & 0.00 & 0.00 & $\begin{array}{l}0.00 \\
\end{array}$ & 0.00 & 0.00 & $\mid 0.00$ & 0.00 & 0.00 & 0.05 \\
\hline Inclusive TTIP & 1.07 & 0.93 & 0.04 & 0.02 & 0.04 & 0.02 & 0.04 & 0.01 & 0.06 & -0.01 & 0.44 & 0.44 & 0.37 & 0.01 & $\begin{array}{l}0.00 \\
\end{array}$ & 0.02 & 0.01 & 0.02 & $\mid 0.00$ & 0.05 & 0.02 & 0.18 \\
\hline Indirect spillovers & 0.05 & 0.03 & 0.03 & 0.02 & 0.03 & 0.02 & 0.05 & 0.02 & 0.04 & 0.04 & 0.03 & 0.02 & 0.01 & 0.01 & \begin{tabular}{|l|l|} 
& 0.01 \\
\end{tabular} & 0.01 & 0.01 & 0.02 & $\mid$\begin{tabular}{l|l} 
& 0.01 \\
\end{tabular} & 0.01 & 0.02 & 0.01 \\
\hline \multirow[t]{3}{*}{ Direct spillovers } & 0.21 & 0.09 & 0.02 & 0.01 & 0.01 & 0.09 & 0.11 & 0.04 & 0.15 & 0.13 & 0.10 & 0.08 & 0.04 & 0.01 & 0.01 & 0.00 & 0.04 & 0.04 & 0.02 & 0.06 & 0.05 & 0.04 \\
\hline & \multicolumn{22}{|c|}{ Welfare } \\
\hline & EUR & USA & CHN & JPN & IND & LAC & OAC & SEA & SSA & MEN & World & EUR & USA & CHN & JPN & IND & LAC & OAC & SEA & SSA & MEN & World \\
\hline Standard TTIP & 1.10 & 0.87 & 0.01 & -0.02 & 0.03 & $\llbracket-0.11$ & -0.15 & -0.06 & 『-0.14 & -0.30 & 0.41 & 0.44 & 0.35 & 0.00 & $\mid-0.02$ & 0.02 & -0.04 & -0.07 & -0.03 & -0.03 & {$[-0.09$} & 0.17 \\
\hline NTBs & 0.64 & 0.36 & 0.01 & -0.01 & 0.03 & -0.10 & -0.12 & -0.05 & ¿-0.15 & -0.30 & 0.18 & 0.23 & 0.12 & 0.00 & -0.01 & 0.01 & -0.03 & -0.04 & -0.02 & -0.04 & -0.08 & 0.07 \\
\hline Tariffs & 0.08 & 0.06 & -0.01 & -0.01 & 0.02 & -0.01 & -0.02 & -0.01 & 0.01 & -0.02 & 0.03 & 0.08 & 0.06 & -0.01 & -0.01 & 0.02 & -0.01 & -0.02 & -0.01 & 0.01 & -0.02 & 0.03 \\
\hline FDI & 0.36 & 0.43 & 0.00 & 0.00 & -0.03 & 0.01 & 0.00 & 0.01 & 0.01 & 0.03 & 0.19 & 0.13 & 0.15 & 0.00 & 0.00 & -0.01 & 0.00 & 0.00 & 0.00 & 0.00 & 0.01 & 0.07 \\
\hline Inclusive TTIP & 1.43 & 1.02 & 0.07 & 0.01 & 0.05 & 0.01 & 0.05 & 0.02 & 0.07 & -0.03 & 0.59 & 0.58 & 0.41 & 0.02 & 0.00 & 0.03 & 0.01 & 0.01 & \begin{tabular}{|l|}
0.00 \\
\end{tabular} & 0.05 & 0.01 & 0.24 \\
\hline Indirect spillovers & 0.07 & 0.03 & 0.04 & 0.01 & 0.06 & 0.02 & 0.06 & 0.02 & 0.04 & 0.04 & 0.04 & 0.03 & 0.01 & 0.01 & 0.01 & 0.02 & 0.01 & 0.02 & 0.01 & 0.02 & 0.01 & 0.02 \\
\hline \multirow[t]{3}{*}{ Direct spillovers } & 0.29 & 0.13 & 0.03 & 0.02 & -0.03 & 0.10 & 0.14 & 0.06 & 0.15 & 0.20 & 0.15 & 0.11 & 0.05 & 0.01 & 0.01 & -0.01 & 0.04 & 0.06 & 0.02 & 0.06 & 0.08 & 0.06 \\
\hline & \multicolumn{22}{|c|}{ Wages } \\
\hline & EUR & USA & CHN & JPN & IND & LAC & OAC & SEA & SSA & MEN & World & EUR & USA & CHN & JPN & IND & LAC & OAC & SEA & SSA & MEN & World \\
\hline Standard & 0.71 & 0.80 & 0.01 & $\mid 0.00$ & 0.01 & -0.09 & -0.09 & -0.05 & -0.10 & -0.14 & 0.32 & 0.32 & 0.34 & 0.00 & \begin{tabular}{l|l|}
0.00 \\
\end{tabular} & \begin{tabular}{|l|}
0.01 \\
\end{tabular} & -0.04 & -0.04 & -0.02 & -0.03 & -0.04 & 0.14 \\
\hline NTBs & 0.41 & 0.34 & 0.01 & 0.01 & 0.02 & -0.08 & -0.07 & -0.04 & -0.11 & -0.14 & 0.14 & 0.14 & 0.12 & 0.00 & \begin{tabular}{l|l|} 
& 0.00 \\
\end{tabular} & 0.00 & -0.02 & -0.02 & -0.01 & -0.03 & -0.04 & 0.05 \\
\hline Tariffs & 0.09 & 0.09 & 0.00 & -0.01 & 0.01 & -0.01 & -0.01 & -0.01 & 0.00 & 0.00 & 0.04 & 0.09 & 0.09 & 0.00 & -0.01 & 0.01 & -0.01 & -0.01 & -0.01 & \begin{tabular}{|l|}
0.00 \\
\end{tabular} & 0.00 & 0.04 \\
\hline FDI & 0.18 & 0.34 & $\begin{array}{l}0.00 \\
\end{array}$ & $\begin{array}{l}0.00 \\
\end{array}$ & -0.02 & 0.01 & 0.00 & 0.00 & 0.01 & 0.01 & 0.13 & 0.07 & 0.12 & 0.00 & 0.00 & 0.00 & 0.00 & 0.00 & 0.00 & \begin{tabular}{|l|}
0.00 \\
\end{tabular} & 0.00 & 0.05 \\
\hline Inclusive TTIP & 0.97 & 0.95 & 0.05 & 0.04 & 0.06 & 0.03 & 0.07 & 0.02 & 0.08 & 0.04 & 0.46 & 0.42 & 0.40 & 0.02 & \begin{tabular}{|l|} 
\\
\end{tabular} & 0.03 & 0.01 & 0.03 & \begin{tabular}{|l|}
0.01 \\
\end{tabular} & 0.04 & 0.03 & 0.19 \\
\hline Indirect spillovers & 0.05 & 0.03 & 0.02 & 0.02 & 0.03 & 0.02 & 0.05 & 0.02 & 0.03 & 0.04 & 0.03 & 0.02 & 0.01 & 0.01 & 0.01 & 0.01 & 0.01 & 0.02 & 0.01 & 0.01 & 0.01 & 0.01 \\
\hline \multirow[t]{3}{*}{ Direct spillovers } & 0.22 & 0.13 & 0.01 & 0.02 & 0.02 & 0.10 & 0.10 & 0.05 & 0.13 & 0.13 & 0.11 & 0.09 & 0.05 & 0.01 & \begin{tabular}{|l|}
0.01 \\
\end{tabular} & 0.01 & 0.04 & 0.04 & 0.02 & 0.05 & 0.05 & 0.04 \\
\hline & \multicolumn{22}{|c|}{ Aggregate exports } \\
\hline & EUR & USA & CHN & JPN & IND & LAC & OAC & SEA & SSA & MEN & World & EUR & USA & CHN & JPN & IND & LAC & OAC & SEA & SSA & MEN & World \\
\hline Standard TTIP & 4.62 & 5.97 & -0.01 & -0.13 & -0.27 & -0.46 & -0.27 & -0.06 & -0.38 & -0.27 & 1.44 & 2.44 & 2.96 & $|-0.02| r \mid$ & -0.07 & -0.16 & -0.21 & -0.12 & -0.04 & -0.11 & -0.08 & 0.75 \\
\hline NTBs & 2.74 & 3.84 & -0.01 & -0.08 & -0.19 & -0.40 & -0.23 & -0.04 & -0.40 & -0.27 & 0.84 & 0.99 & \begin{tabular}{|l|l|}
1.35 \\
\end{tabular} & $|-0.01|$ & -0.03 & -0.06 & -0.13 & -0.08 & -0.02 & -0.11 & -0.08 & 0.31 \\
\hline Tariffs & 1.15 & 1.38 & -0.03 & -0.03 & -0.10 & -0.08 & -0.05 & -0.02 & -0.02 & -0.01 & 0.35 & 1.15 & 1.38 & $|-0.03|$ & -0.03 & -0.10 & -0.08 & -0.05 & -0.02 & -0.02 & -0.01 & 0.35 \\
\hline FDI & \begin{tabular}{|l|l|}
0.37 \\
\end{tabular} & 0.33 & \begin{tabular}{l|l|}
0.02 & \\
\end{tabular} & -0.01 & 0.04 & 0.05 & \begin{tabular}{l|l|}
0.02 \\
\end{tabular} & 0.01 & \begin{tabular}{|l|l|}
0.04 & \\
\end{tabular} & \begin{tabular}{l|l|}
0.01 & \\
\end{tabular} & 0.13 & 0.17 & 0.08 & 0.01 & 0.00 & 0.01 & 0.01 & 0.01 & 0.00 & \begin{tabular}{|l|l|} 
& 0.01 \\
\end{tabular} & 0.01 & 0.05 \\
\hline Inclusive TTIP & 5.69 & 7.29 & 0.24 & 0.00 & -0.05 & 0.27 & \begin{tabular}{|l|}
0.10 \\
\end{tabular} & 0.1 & $\mid 0.23$ & $\mid 0.2$ & 2.06 & 2.88 & 3.51 & 0.08 & -0.02 & -0.07 & 0.08 & \begin{tabular}{|l|} 
\\
\end{tabular} & 0.03 & \begin{tabular}{|l|} 
\\
\end{tabular} & 0.11 & 1.00 \\
\hline Indirect spillovers & 0.32 & 0.30 & 0.13 & 0.07 & 0.00 & 0.20 & 0.15 & 0.08 & 0.12 & 0.16 & 0.18 & 0.13 & 0.12 & 0.05 & 0.03 & 0.00 & 0.08 & 0.06 & 0.03 & 0.05 & 0.06 & 0.07 \\
\hline \multirow[t]{3}{*}{ Direct spillovers } & 0.79 & 1.11 & 0.13 & 0.05 & 0.22 & 0.52 & 0.21 & 0.10 & 0.45 & 0.29 & 0.45 & 0.31 & 0.44 & 0.05 & 0.02 & 0.09 & 0.21 & \begin{tabular}{|l|}
0.09 \\
\end{tabular} & 0.04 & 0.18 & 0.12 & 0.18 \\
\hline & \multicolumn{22}{|c|}{ Aggregate imports } \\
\hline & EUR & USA & CHN & JPN & IND & LAC & OAC & SEA & SSA & MEN & World & EUR & USA & CHN & JPN & IND & LAC & OAC & SEA & SSA & MEN & World \\
\hline Standard TTIP & \begin{tabular}{|l|}
4.60 \\
\end{tabular} & 4.42 & \begin{tabular}{l|l|}
0.02 \\
\end{tabular} & -0.10 & $\mid-0.05$ & $|-0.48|$ & $\mid-0.28$ & -0.06 & -0.32 & -0.48 & 1.44 & \begin{tabular}{|l|}
2.39 \\
\end{tabular} & 2.22 & $|-0.01|$ & -0.06 & $|-0.02|$ & -0.22 & -0.13 & -0.04 & $\mid-0.08$ & -0.15 & 0.75 \\
\hline NTBs & \begin{tabular}{|l|}
2.82 \\
\end{tabular} & 2.74 & 0.01 & -0.06 & -0.04 & -0.42 & -0.24 & -0.04 & -0.34 & -0.49 & 0.84 & \begin{tabular}{|l|}
1.02 \\
\end{tabular} & 0.97 & 0.00 & -0.02 & -0.01 & -0.14 & -0.08 & -0.02 & -0.09 & -0.13 & 0.31 \\
\hline Tariffs & 1.16 & 0.99 & -0.02 & -0.04 & 0.00 & -0.09 & -0.05 & -0.02 & 0.00 & -0.03 & & 1.1 & 0.99 & \begin{tabular}{|l|}
-0.02 \\
\end{tabular} & -0.04 & 0.00 & -0.09 & -0.05 & -0.02 & 0.00 & -0.03 & 0.35 \\
\hline FDI & 0.26 & 0.38 & \begin{tabular}{|l|}
0.02 \\
\end{tabular} & 0.00 & -0.01 & \begin{tabular}{|l|} 
\\
\end{tabular} & $\begin{array}{l}0.02 \\
\end{array}$ & 0.01 & \begin{tabular}{l|l|} 
& 0.02 \\
\end{tabular} & \begin{tabular}{|l|l|} 
& 0.04 \\
\end{tabular} & 0.13 & 0.09 & 0.15 & \begin{tabular}{|l|l|}
0.01 & \\
\end{tabular} & 0.00 & 0.00 & 0.01 & \begin{tabular}{|l|}
0.01 \\
\end{tabular} & 0.01 & \begin{tabular}{|l|l|} 
& 0.01 \\
\end{tabular} & 0.02 & 0.05 \\
\hline Inclusive TTIP & \begin{tabular}{|l|l|}
5.67 \\
\end{tabular} & \begin{tabular}{|l|l|}
5.34 \\
\end{tabular} & 0.28 & 0.10 & 0.04 & 0.33 & 0.18 & 0.14 & 0.24 & 0.23 & 2.06 & \begin{tabular}{|l|}
2.83 \\
\end{tabular} & 2.60 & 0.09 & 0.02 & 0.02 & 0.10 & 0.05 & 0.04 & 0.13 & 0.12 & 1.00 \\
\hline Indirect spillove & 0.31 & 0.20 & 0.13 & 0.08 & 0.06 & 0.2 & 0.16 & 0.08 & 0.13 & 0.15 & 0.18 & 0.1 & 0.08 & 0.05 & 0.03 & $\begin{array}{l}0.02 \\
\end{array}$ & 0.09 & 0.07 & 0.03 & \begin{tabular}{ll|} 
\\
\end{tabular} & 0.07 & 0.07 \\
\hline Direct spillovers & 0.81 & 0.79 & 0.13 & 0.12 & 0.04 & 0.57 & 0.29 & 0.11 & 0.39 & 0.48 & 0.45 & 0.32 & 0.31 & 0.05 & 0.05 & 0.01 & 0.23 & 0.12 & 0.05 & 0.16 & 0.19 & 0.18 \\
\hline
\end{tabular}

Source: Authors' estimations.Note: See note in Table 6. 
The inclusion of FDI makes our estimations surpass the ones from previous influential CGE studies (such as, Francois et al., 2013 and Fontagne et al., 2013), being closer to the ones of Egger et. al (2015) and still far from the very large ones of Felbermayr et al., $(2013 ; 2015)^{18}$. The impact of FDI would be larger for the US than for the EU. In the US, FDI would contribute to nearly half of the overall effects of TTIP in terms of both GDP and welfare, while in the EU it would be nearly one third. As noted above, FDI barriers are larger in the US than in the EU, particularly in the big sector of business services. When they are lowered, productive capital enters intensively in the US economy. This more favorable impact of FDI for the US compensates the relatively smaller one, compared to the EU, in trade NTBs. Thus, our results lie somewhat in between what Egger et al. (2015) and Felbermayr et al. (2013; 2015) obtain. The former obtain that TTIP is more beneficial for the EU due to trade NTBs, while for the latter the impact is much more positive in the US. Note that the inclusion of FDI has a nearly negligible impact for outsiders. Therefore, FDI is also an important element to raise the overall impact of world GDP and welfare which would increase by $0.31 \%$ and $041 \%$, respectively. The former figure is slightly higher than the increase derived in output (Table 5), because more world production would be made in advanced areas, in which value added per unit produced is larger than in developing areas.

In the evolution of wages, we find that wages of American workers would increase slightly more after the TTIP than those of EU workers. This effect is also related to the FDI component neglected in previous analysis. Even with the presence of profit repatriation, American workers (and to a lesser extent European ones) would experience sizeable increase in wages. Wages of outsiders have the same pattern as their GDP results.

Let us turn now to the analysis of an "inclusive TTIP", which takes into account regulatory spillovers. The TTIP is to a great extent an agreement about streamlining of regulations and standards. Because the US and the EU constitute the world's biggest trading block, the TTIP could become a regulatory hegemon in the sense that other countries could adopt, at least partially, some of the standards agreed between the EU and the US. This would allow those third countries to export to the big markets of the US and EU using the same standards, which would make them save costs and achieve economies of scale. Felbermayr et al. (2015) and Egger et al. (2015) have expressed their doubts about this possibility that the TTIP could establish world standards, thus, implying this sort of spillovers. By contrast, Hufbauer and Cimino-Isaacs (2015) and Baldwin, as noted in the discussion of Felbermayr et al. (2015) and developed in Baldwin (2014; 2015) has a different view. He explains how previous integration processes, like the EU common market and the Japan-Thailand trade agreement, have not ended up being discriminatory to third countries, despite previous concerns about it (such as the idea of "Fortress Europe").

The "inclusive TTIP” adds to the previous "standard TTIP” two new components analyzed separately, "direct spillovers" and "indirect spillovers" ${ }^{19}$. With "direct spillovers" we model outsiders exporting to the EU and US saving $20 \%$ of the costs of the NTBs reductions agreed with the TTIP. This implies that from the cost reductions related to NTBs in trade displayed in Table 1, outsiders would reduce

\footnotetext{
${ }^{18}$ Francois et al. (2013) obtain that EU GDP would grow by $0.48 \%$ and the US GDP by $0.39 \%$ in their ambitious long run scenarios including spillovers. Fontagné et al. (2013) estimate a 0.3\% increase in GDP for both the EU and the US, also in their ambitious scenarios with no spillovers. Egger et al. (2015) use structural gravity to derive the impact of TTIP on trade flows and then introduce those results in the same CGE model of Francois et al. (2013). Importantly, they also re-estimate NTBs which turn out to be larger than the ones of Ecorys (2009) used here and in Francois et al. (2013). As a result, they obtain a much larger impact than in Francois et al. (2013), which is much more positive for the EU than for the US. Felbermayr et al. (2013) obtain an increase in GDP per capita of 13.4 in the US. For the different countries of the EU27 (which, interestingly, are evaluated individually) GDP per capita increases range from 2.58 in Austria to 9.7 in the UK, with an unweighted average of 8.0. Given that population growth is slow in the developed world, the estimates of Felbermayr et al. (2013) look very high. In fact, in a later study using the same structural gravity model (Felbermayr et al., 2015), the estimates are much more reduced although still much larger than ours. They calculate that GDP per capita would increase by $3.9 \%, 4.9 \%$ and $1.5 \%$ in the EU, the US and the world, respectively.

${ }^{19}$ Francois et al. (2013, pp. 28-29) explain in detail the direct and indirect spillovers effects that we follow. Petri and Plumer (2016) also adopt spillovers in their analysis of the Trans Pacific Partnership.
} 
their costs in one fifth of the figures appearing in the first four columns. We also model "indirect spillovers". In this latter simulation the TTIP area (i.e., both the US and the EU) gain by saving $10 \%$ of their costs (i.e., one tenth of the figures in the first four columns of Table 1) when they export to third countries. This should grasp the extra push for EU and US trade if outsiders adopt some of their commonly agreed standards. In sum, the scenario "inclusive TTIP" runs simultaneously the "standard TTIP" (including the three components of NTBs, tariffs and FDI) together with the direct and indirect spillovers.

What changes in the "inclusive TTIP”? First, spillovers reduce negative trade diversion for outsiders. Therefore, all areas now exhibit a tiny positive impact (only Middle-East would remain with a $-0.1 \%$ change in GDP, a $-0.03 \%$ in welfare but with rising wages). This contrasts with the slightly negative effects we had seen with the "standard TTIP". Second, the TTIP partners gain considerably more in this scenario in which world trade increases more heavily than in the "standard TTIP". These results, point to the much larger gains for all if negotiations are done in an "inclusive" way (i.e., avoiding discriminatory rules and standards).

Another important result from the regulatory spillovers is that their impact is asymmetric compared to what we had obtained with the standard TTIP. In other words, the regions that were previously less negatively affected (i.e., China and the other Asiatic countries and regions) seem to gain less with spillovers. By contrast, the regions that experienced mild but somewhat larger losses now benefit more. Thus, the Middle-East turns from a $-0.20 \%$ GDP fall into a $-0.01 \%$ change in GDP and SubSaharan Africa turns from $-0.14 \%$ to a $0.06 \%$ increase. We can see that this positive impact is mostly concentrated in the direct spillovers, in which the largest cost savings of $20 \%$ take place. What happens is that with these larger savings the sectors of other primary, agriculture and food, which are critical in their export structure, turn to be more competitive expanding exports and output.

Other advanced countries and Latin America follow the Middle East and Sub-Saharan areas as winners, when spillovers are accounted for. Their positive evolution is related to the fact that the fall in output from manufacturing is smaller than with no spillovers. Manufacturing exports are increasing not only in the Middle East and Sub-Saharan Africa but also in Latin America and Other advanced countries. At the same time, exports from services sectors are also increasing by more in these areas. This will result in an expansion of services sectors, while they were reducing output with the standard TTIP. Higher competition in exports of manufacturing will slightly hurt Chinese manufacturing output, which gains relatively less with the spillovers. Furthermore, because India, Japan and East Asia are also highly specialized in manufacturing exports, this trend will also be relatively less beneficial for them.

All in all, an "inclusive TTIP" would be in the benefit of both insiders, who gain more, and outsiders, who are also better off than without the TTIP agreement. Further, if the TTIP were inclusive world GDP could grow by a non-negligible $0.44 \%(0,18 \%)$ in an ambitious (modest) scenario.

\section{Sensitivity analysis}

Table 9 presents the results for an Unconditional Systematic Sensitivity Analysis. Following Harrison et al. (1993), we vary each of the elasticities one by one, while keeping the rest fixed at their initial level. We run the strongest possible impact of the standard TTIP (i.e., the long run effect of an ambitious agreement). The first row offers the results we have been analyzing throughout the paper, for the sake of comparison. To simplify, we focus now on the effects for GDP.

The outcomes for outsiders do not vary significantly when we change the elasticities except Armington elasticity, which we discuss further below. Thus, aside from the case of changing Armington elasticities, the trends should already be familiar to us. China is unaffected and so are India 
and Japan to a great extent. The Middle East and Sub-Saharan Africa are the most negatively affected, even though the impact is limited.

Some elasticities are somewhat more likely to affect the impact for the TTIP partners, such as the supply elasticity with respect to the price of output of firms in services sectors (i.e., $\varepsilon$ (fi)). Higher (lower) value of this elasticity means that the firms in both manufacturing and service sectors will not be so (will be more) easily constrained by the larger cost of the specific factor requirement. Since the elasticities in service sectors are higher than in manufacturing sectors, the change of this effect is strongly related with the FDI reform.

Table 9. Sensitivity analysis: Impact on GDP

\begin{tabular}{|c|c|c|c|c|c|c|c|c|c|c|}
\hline & EUR & USA & $\mathrm{CHN}$ & IND & JPN & LAC & MEN & OAC & SEA & SSA \\
\hline Reference & 0.82 & 0.82 & 0.00 & 0.00 & -0.01 & -0.09 & -0.20 & {$[-0.12$} & -0.05 & -0.14 \\
\hline$\theta \mathrm{r}(\mathrm{i})(25 \%)$ & 0.79 & 0.80 & 0.00 & 0.00 & -0.01 & -0.09 & -0.20 & -0.12 & -0.05 & -0.14 \\
\hline$\theta \mathrm{r}(\mathrm{i})(75 \%)$ & 0.85 & 0.84 & 0.00 & 0.00 & -0.01 & -0.09 & -0.20 & -0.12 & -0.05 & -0.14 \\
\hline 25\% Profit repatiation & 0.82 & 0.74 & 0.00 & 0.01 & -0.01 & -0.11 & -0.20 & -0.12 & -0.05 & -0.15 \\
\hline 75\% Profit repatiation & 0.81 & 1.02 & 0.00 & -0.02 & -0.01 & -0.08 & -0.20 & {$[-0.11$} & -0.05 & []-0.14 \\
\hline$\sigma(\mathrm{D}, \mathrm{M})($ high $)$ & 0.82 & 0.81 & 0.00 & -0.01 & -0.01 & -0.06 & -0.17 & -0.09 & -0.03 & -0.11 \\
\hline$\sigma(\mathrm{D}, \mathrm{M})(\mathrm{low})$ & 0.82 & 0.83 & 0.01 & 0.01 & -0.01 & -0.13 & -0.23 & -0.15 & -0.06 & -0.19 \\
\hline$\sigma(\mathrm{M}, \mathrm{M})$ (high) & 0.95 & 1.00 & 0.02 & 0.01 & -0.01 & -0.19 & -0.40 & -0.23 & -0.09 & -0.32 \\
\hline$\sigma(\mathrm{M}, \mathrm{M})(\mathrm{low})$ & 0.73 & 0.70 & 0.00 & -0.02 & -0.02 & -0.03 & -0.07 & -0.04 & -0.02 & -0.03 \\
\hline$\sigma(q i$, qj) (goods, high) & 0.83 & 0.85 & 0.00 & 0.00 & -0.01 & -0.10 & -0.21 & -0.12 & -0.05 & -0.15 \\
\hline$\sigma(q i, q j)$ (goods, low) & 0.91 & 0.82 & 0.01 & 0.01 & -0.02 & -0.08 & -0.18 & -0.11 & -0.04 & {$[-0.12$} \\
\hline$\theta \mathrm{m}$ (i) (high) & 0.83 & 0.84 & 0.00 & 0.00 & -0.01 & -0.09 & -0.20 & -0.12 & -0.05 & -0.14 \\
\hline$\theta \mathrm{m}$ (i) (low) & 0.81 & 0.79 & 0.00 & 0.00 & -0.01 & -0.09 & -0.20 & -0.11 & -0.05 & -0.14 \\
\hline$\sigma(\mathrm{A} 1, \ldots, \mathrm{An})$ (alternative) & 0.82 & 0.82 & 0.00 & 0.00 & -0.01 & -0.09 & -0.19 & -0.11 & -0.05 & -0.14 \\
\hline$\varepsilon$ (fi) (high) & 1.02 & 1.30 & 0.00 & -0.04 & -0.02 & -0.08 & -0.22 & -0.13 & -0.05 & -0.15 \\
\hline$\varepsilon$ (fi) (low) & 0.61 & 0.69 & 0.00 & 0.01 & -0.01 & -0.10 & -0.20 & -0.12 & -0.05 & {$[-0.14$} \\
\hline$\sigma$ (qi, qj) (services, high) & 0.74 & 0.76 & 0.00 & 0.00 & -0.01 & -0.09 & -0.20 & ] -0.12 & -0.05 & -0.14 \\
\hline$\sigma(\mathrm{qi}, \mathrm{qj})$ (services, low) & 1.02 & 0.95 & 0.01 & 0.00 & -0.01 & -0.09 & -0.19 & [ -0.11 & -0.04 & -0.14 \\
\hline$\sigma$ (va, bs) (high) & 1.02 & 0.97 & 0.01 & 0.01 & -0.01 & -0.08 & -0.18 & -0.10 & -0.03 & -0.13 \\
\hline$\sigma(\mathrm{va}, \mathrm{bs})(\mathrm{low})$ & 0.70 & 0.72 & 0.00 & 0.00 & -0.01 & -0.10 & -0.21 & -0.13 & -0.05 & -0.15 \\
\hline$\sigma(\mathrm{L}, \mathrm{K})($ high $)$ & 0.99 & 0.92 & 0.01 & 0.00 & -0.01 & -0.11 & -0.21 & -0.12 & -0.06 & -0.15 \\
\hline$\sigma(\mathrm{L}, \mathrm{K})(\mathrm{low})$ & 0.66 & 0.72 & 0.00 & 0.00 & -0.01 & -0.07 & -0.17 & [-0.11 & -0.03 & {$[-0.12$} \\
\hline
\end{tabular}

$\begin{array}{ll}\theta \mathrm{r}(\mathrm{i}) & \text { Shares of rents in services sectors captured by domestic agents } \\ \sigma(\mathrm{D}, \mathrm{M}) & \text { Armington elasticity of substitution between imports and domestic goods in CRTS sectors } \\ \sigma(\mathrm{M}, \mathrm{M}) & \text { Armington elasticity of substitution between imports from different regions in CRTS sectors } \\ \theta \mathrm{m}(\mathrm{i}) & \text { Share of value added in multinational firms in sector i due to specialized primary factor imports in the benchmark } \\ \sigma(\mathrm{A} 1, \ldots, \mathrm{An}) & \text { Elasticity of substitution in intermediate production between composite Armington aggregate goods } \\ \sigma(\mathrm{qi}, \mathrm{qi})(\text { goods }) & \text { Elasticity of substitution between firm varieties in imperfectly competitive goods sectors } \\ \sigma(\mathrm{qi}, \mathrm{qj}) \text { (services) } & \text { Elasticity of substitution between firm varieties in imperfectly competitive services sectors } \\ \varepsilon(\mathrm{fi}) & \text { Elasticity of supply with respect to price of output in national firms and multinationals in services } \\ \sigma(\mathrm{va}, \mathrm{bs}) & \text { Elasticity of substitution between value-added and business services } \\ \sigma(\mathrm{L}, \mathrm{K}) & \text { Elasticity of substitution between primary factors of production in value added }\end{array}$

Source: Authors' estimations.

Note: See note in Table 6.

The only change in elasticities that significantly affects outsiders is the Armington elasticity of substitution between imports from the different regions in constant return to scale sectors (i.e., $\sigma(\mathrm{M}$, $\mathrm{M})$ ). A higher value for this elasticity means that substituting imports from one region to another would be easier. For example, the EU can substitute the import from Middle-East with the import from 
US more easily, which enhances the trade diversion. This trade diversion results in the positive impact on the insiders of the TTIP, whereas it results in the negative impact on the outsiders. Conversely, with a lower value for this elasticity, such trade diversion would be smaller, and accordingly the GDP impact would be smaller. As a result, higher (lower) values of this elasticity increase (decrease) the impact of FDI. When its value is high, GDP gains are considerably larger in the US than in the EU because, as we have described, the US is the region that obtains a more favorable shock from FDI. Regarding the substitution elasticities, following from the Le Chatelier principle, higher (lower) values of elasticities make corresponding aspects of the economy more (less) flexible and typically result in larger (smaller) increases in GDP than in the central case. Larger values for the Elasticity of substitution between value-added and business services (i.e., $\sigma(\mathrm{va}, \mathrm{bs})$ ) make it possible to gain more from the increase in the number of firms in services sectors due to FDI. Similarly, the larger the elasticity of substitution between factors of production (i.e., $\sigma(\mathrm{L}, \mathrm{K})$ ) the stronger the impact of TTIP. Only one exception arises from this tendency of higher values for substitution elasticities leading to better GDP outcomes. The elasticity of substitution between firm varieties in imperfectly competitive services sectors (i.e., $\sigma$ (qi, qj) (services)) works differently. What happens is that a lower elasticity makes the new varieties of services more valuable, since they are more different and difficult to substitute for one another. Because a new variety of services "brings more" with this lower elasticity, the impact of FDI is increased leading to a stronger overall impact of the TTIP.

All in all, the effects of TTIP look very robust with different elasticity specifications, providing further evidence for our results.

\section{Conclusions}

In this paper, we extend the CGE model by Balistreri et al. (2015) to analyze what the effects of the TTIP would have been. The analysis covers the impact on the partners of the agreement and on outsiders, as well as on the world economy. The model exhibits an important innovative feature in terms of CGE modelling, namely, the consideration of foreign multinationals and Foreign Direct Investment (FDI) flows in a multiregional framework with imperfect competition. We model foreign affiliates' sales in services (Mode 3). This is of relevance since FDI is an essential part of the agreement and the TTIP area concentrates the largest shares of FDI inward and outward stocks in the world.

The introduction of FDI considerably increases the positive impact of the TTIP for the US and for the EU. Our estimations, therefore, surpass the previous ones obtained with other influential CGE models (i.e., Francois et al., 2013; Fontagne et al. 2013). The results we derive lie somewhat in between what Egger et al. (2015) and Felbermayr et al. (2013; 2015) obtain. The former find that TTIP would be more beneficial for the EU due to trade NTBs. By contrast, according to Felbermayr et al. (2013; 2015) the impact would be much more positive in the US, based on evidence from previous trade agreements. We obtain a more balanced outcome, due to the impact of FDI. The latter would be larger for the US than for the EU. In the US, FDI would contribute to nearly half of the overall effects of TTIP in terms of both GDP and welfare, while in the EU it would be nearly one third. Because FDI barriers are larger in the US than in the EU, if the TTIP lowered those barriers more productive capital would enter intensively in the US economy. This more favorable impact of FDI for the US would compensate the relatively smaller one, compared to the EU, in trade NTBs.

On the other hand, the effects of the TTIP would be negative (although the magnitude would be modest) for outsiders, with the exception of China, which would remain unaffected. This is because the Chinese export structure is heavily specialized precisely in the manufacturing sectors in which integration of the EU and the US after the TTIP is not very strong. Furthermore, we find evidence for an "Asiatic pattern" by which Japan and India would be hardly affected either, and South East Asia would lose only slightly. By contrast, the Middle East and Sub-Saharan Africa would be the most 
negatively impacted because their export specialization in agriculture, food, oil and mining is particularly harmed. Latin America and Other Advanced Countries would also lose slightly due to its export specialization and close trade connections with the US (for the former) and with both of the TTIP partners (for the latter). However, we do not find evidence for a zero sum game of trade. Instead, the world economy would have gained in all TTIP scenarios (i.e., with both a shallow or deep version), which have been modelled as modest or ambitious, respectively.

Last but certainly not least, it seems that there could be a way of negotiating the TTIP which would turn it slightly beneficial for all outsiders. We have simulated it as an "inclusive TTIP", following the literature. This would imply avoiding discriminatory rules and regulations against outsiders. Our estimations point out that this would be good not only for outsiders but also for the TTIP partners themselves. The impact on GDP, welfare, wages, as well as on aggregate imports and exports would be more beneficial for both insiders and outsiders if the TTIP could become a regulatory hegemon, capable of setting global standards of modern trade elements that third countries could adopt. In fact, the results suggest that under this scenario gains for the world economy could be quite sizeable with a $0.44 \%$ and $0.59 \%$ increase in world GDP and welfare, respectively.

\section{References}

Antràs, P. and Staiger, R.W. (2012a). Offshoring and the Role of Trade Agreements. American Economic Review, vol. 102, pp. 3140-3183.

Antràs, P. and Staiger, R.W. (2012b). Trade Agreements and the Nature of Price Determination. American Economic Review: Papers \& Proceedings, vol. 102, pp. 470-476.

Arkolakis, C, Ramondo, N., Rodríguez-Clare, A. and Yeaple, S. (2015). Innovation and Production in the Global Economy, NBER Working Paper Series 18972.

Arnold, J., Mattoo, A. and Gaia, N. (2008). Services Inputs and Firm Productivity in Sub-Saharan Africa: Evidence from Firm Level Data. Journal of African Economies, vol. 17, pp. 578-599.

Alviarez, V., Cravino, J and Levchenko, A. A. (2016) The growth of multinational firms in the Great Recession. Journal of Monetary Economics, forthcoming.

Baldwin, R. (2015). The World Trade Organization and the future of multilateralism, CEPR Discussion Paper No. 11021, December 2015.

Baldwin, R. E. (2014). Multilateralising 21st Century Regionalism, paper presented at the Global Forum On Trade Reconciling Regionalism and Multilateralism In a Post-Bali World, OECD Conference Centre, Paris, February, 2014.

Balistreri, E. J., Tarr D. G., and Yonezawa, H. (2015). Deep Integration in Eastern and Southern Africa: What are the Stakes?. Journal of African Economics, vol. 24(5), 677-706.

Bekkers, E. y Rojas-Romagosa, H. (2016). Quantitative trade models and the economic assessment of TTIP, Paper presented at the 19th GTAP conference, Washington D.C., June. (ISSN 2160-2115)

Böhringer, C., Löschel, A., Moslener, U. and Rutherford, T.F. (2009). EU climate policy up to 2020: an economic impact assessment. Energy Economics. 31, S295-S305.

Broda, C. and Weinstein, D. (2006). Globalization and the Gains from Variety. Quarterly Journal of Economics, vol. 121, pp. 541-85. 
Burstein, Ariel, Monge-Naranjo, Alex, 2009. Foreign know-how, firm control, and the income of developing countries. Quarterly Journal of Economics, 124 (1): 149-195.

Capaldo, Jeronim (2014). The Trans-Atlantic Trade and Investment Partnership: European Disintegration, Unemployment and Instability, Global Development and Environment Institute Working Paper No. 14-03, Tufts University, October.

CEPR (2013). Estimating the Economic Impact on the UK of a Transatlantic Trade and Investment Partnership (TTIP) Agreement between the European Union and the United States, Final Project Report, Centre for Economic Policy Research, London, March.

Ciuriak, D. and Xiao, Jingliang (2014b). The Trans-Pacific Partnership: Evaluating the Landing Zone‘ for Negotiations, Working Paper.

Ecorys (2009). Non-Tariff Measures in EU-US Trade and Investment - An Economic Analysis, Report prepared by Berden, K., J. Francois, M. Thelle, P. Wymenga and S. Tamminen for the European Commission, Reference OJ 2007/S180-219493.

Egger, P., J. Francois, M. Manchin, and D. Nelson (2015). Non-tariff Barriers, Integration, and the Transatlantic Economy. Economic Policy, vol. 30, no.83, pp. 541-548.

Felbermayr, G.J., Heid, B. and Lehwald, S. (2013). Transatlantic Trade and Investment Partnership (TTIP): Who benefits from a free trade deal?, Bertelsmann Stiftung.

Felbermayr, G., B. Heid, M. Larch, and E. Yalcin (2015). Macroeconomic Potentials of Transatlantic Free Trade: A High Resolution Perspective for Europe and the World. Economic Policy, vol. 30, no.83, pp. 491-537.

Fernandes, A. M. and Paunov, C. (2012). Foreign direct investment in services and manufacturing productivity: evidence for Chile. Journal of Development Economics, vol. 97, pp. 305-321

Fontagne, L., J. Gourdon and Jean, S. (2013). Transatlantic Trade: Whither Partnership, Which Economic Consequences?, CEPII Policy Brief No. 1, September, 2013.

Francois, J., Manchin M., Norberg H., Pindyuk O. and Tomberger P. (2013). Reducing Transatlantic Barriers to Trade and Investment, An Economic Assessment, Study for the European Commission, CEPR Report.

Fukui, T. and Lakatos, C. (2012). A Global Database of Foreign Affiliate Sales, GTAP Research Memoranda 4009, Center for Global Trade Analysis, Department of Agricultural Economics, Purdue University.

Goldberg, P., Khandelwal, A, Pavcnik, N. and Topalova, P. (2009). Trade Liberalization and New Imported Inputs. American Economic Review Papers and Proceedings, vol. 99, pp. 494-500.

Gómez-Plana, A. G. and Latorre, M.C. (2014). When multinationals leave: A CGE analysis of divestments. Economics-The Open Access Open-Assessment E-Journal, vol. 8, pp. 1-41, available at: http://www.economics-ejournal.org/economics/journalarticles/2014-6

Harrison, G. W., Jones, R.E., Kimbell, L. J. \& Wigle, R. M. 1993. How Robust Is Applied General Equilibrium Analysis. Journal of Policy Modeling, vol. 15(1): 99-115.

Helpman, E. and Krugman, P. (1985). Market Structure and Foreign Trade, Cambridge MA: MIT Press.

Hufbauer, G.C and Cimino-Isaacs, C. (2015). How will TPP and TTIP change the WTO system?, Journal of International Economic Law, vol. 18, pp. 679-696. 
IMF (2015). World Economic Outlook: Database, Abril, https://www.imf.org/external/pubs/ft/weo/2015/01/weodata/index.aspx

Jafari, Y. and Tarr, D.G. (2015). Estimates of Ad Valorem Equivalents of Barriers Against Foreign Suppliers of Services in Eleven Services Sectors and 103 Countries. The World Economy.

Koske, I., Wanner, I., Bitetti, R. and Barbiero, O. (2015). The 2013 update of the OECD's database on product market regulation: Policy insights for OECD and non-OECD countries, OECD Economics Department Working Papers, No. 1200, OECD Publishing, http://dx.doi.org/10.1787/5js3f5d3n2vl-en

Krugman, P. (1980). Scale Economies, Product Differentiation, and the Pattern of Trade. American Economic Review, vol. 70, pp. 950-59.

Lakatos, C., and Fukui, T. (2014). The liberalization of retail services in India. World Development, vo. 59, pp. 327-340.

Latorre, M.C. (2009). The economic analysis of multinationals and foreign direct investment: A review. Hacienda Pública Española/Revista de Economía Pública, vol. 191, pp. 97-126.

Latorre, M. C. (2012). Industry restructuring in transition after the arrival of multinationals: A general equilibrium analysis with firm-type costs' differences. Post-communist economies, vol. 24, p. 441463.

Latorre, M. C. (2013). On the differential behaviour of national and multinational firms: A within and across sectors approach. The World Economy, vol. 36, pp. 1245-1372.

Latorre, M. C. (2016). A CGE analysis of the impact of foreign direct investment and tariff reform on female and male workers. World Development, vol. 77, pp. 346-366.

Latorre, M. C. and Hosoe, N. (2016). The role of Japanese FDI in China. Journal of Policy Modeling, vol. 38, pp. 226-241.

Latorre, M. C., Bajo-Rubio, O. and Gómez-Plana, A. G. (2009). The effects of multinationals on host economies: A CGE approach. Economic Modelling, vol. 26, pp. 851-864.

Lawrence, R. Z. (2003). Crimes \& Punishments?: Retaliation Under The WTO, Institute For International Economics, Washington, DC, October.

Lester, S. (2017) “The TPP is dead. Spare the TTIP”, CATO Institute, Commentary, February 8 2017, available at: https://www.cato.org/publications/commentary/tpp-dead-spare-ttip

Maggi, G. (2014). International Trade Agreements in G. Gopinath, E. Helpman and K. Rogoff, eds., Handbook of International Economics, vol. 4, pp. 317-390.

McGrattan, E. \& Prescott, E., 2009. Openness, technology capital, and development. Journal of Economic Theory, 144 (6): 2454-2476.

Narayanan, G., B., Aguiar, A. and McDougall, R. (Eds.) (2015a). Global Trade, Assistance, and Production: The GTAP 9 Data Base, Center for Global Trade Analysis, Purdue University.

Oleseyuk, Z. (2015). The EU-Ukraine Deep and Comprehensive Free Trade Agreement and the Importance of FDI, paper presented at the 18th Annual Conference on Global Economic Analysis, June 17-19, 2015, Melbourne, Australia.

Petri, P. and Plummer, M. (2016). The Economic Effects of the Trans-Pacific Partnership: New Estimates, Peterson Institute for International Economics, Working Paper 16-2. Available at: http://www.iie.com/publications/wp/wp16-2.pdf 
Rutherford, T. F. and Tarr, D. G. (2008). Poverty effects of Russia’s WTO accession: Modeling "real” households with endogenous productivity effects. Journal of International Economics, vol. 75, pp. $131-150$.

Ramondo, N. 2014. A quantitative approach to multinational production. Journal of International Economics, 93 (1): 108-122

Ramondo, N. \& Rodríguez-Clare, A. 2013. Trade, multinational production, and the gains from openness. Journal of Political Econonomy, 121 (2): 273-322.

Shoven, J. B. and Whalley, J. (1984). Applied general-equilibrium models of taxation and international trade: An introduction and survey. Journal of Economic Literature, vol. 22, pp. 10071051.

Smarzynska, B. (2004). Does foreign direct investment increase the productivity of domestic firms? In search of spillovers through backward linkages. American Economic Review, vol. 94, pp. 605-627.

Tarr, D. G. (2012). Putting Services and Foreign Direct Investment with Endogenous Productivity Effects in Computable General Equilibrium Models in Dixon, P. And Jorgenson, D. (Eds.) Handbook of Computable General equilibrium modeling, Elsevier, North-holland.

The Economist (2017). The world, watching; How America's allies see it, February 4, 2017.

UNCTAD (several years). World Investment Report, United Nations, New York and Geneva.

Wall Street Journal (2016). Japan ratifies Trans-Pacific Partnership, which Trump has promised to leave, 9 December 2016.

Zhou, J. and Latorre, M. C. (2014a). How does FDI influence the triangular trade pattern among China, East Asia and the U.S.? A CGE analysis of the sector of Electronics in China. Economic Modelling, vol. 44, Supplement, pp. S77-S88.

Zhou, J. and Latorre, M. C. (2014b). The impact of FDI on the production networks between China and East Asia and the role of the U.S. and ROW as final markets. Global Economic Review: Perspectives on East Asian Economies and Industries, vol. 43, pp. 285-314. 


\begin{tabular}{|c|c|c|c|}
\hline Sectors & Nace Rev 2 & Isic Rev 3.1 & GTAP \\
\hline 1.Agriculture & A Agriculture, forestry and fishery products & ISIC $01-05$ & $1-14$ \\
\hline 2.Other primary & B Mining and quarrying & ISIC $10-14$ & $15-18$ \\
\hline \multirow{3}{*}{ 3.Food } & C10 Manufacture of food products & \multirow{3}{*}{ ISIC $15-16$} & \multirow{3}{*}{$19-26$} \\
\hline & C11 Manufacture of beverages & & \\
\hline & C12 Manufacture of tobacco products & & \\
\hline \multirow{3}{*}{ 4. Textiles } & C13 Manufacture of textiles & & \multirow{3}{*}{$27-29$} \\
\hline & C14 Manufacture of wearing apparel & & \\
\hline & C15 Manufacture of leather and related products & & \\
\hline \multirow[b]{2}{*}{ 5. Wood and paper } & C16 Manufacture of wood and of products of wood, cork, straw and plaiting materials & \multirow[b]{2}{*}{ ISIC 20-22 } & \multirow[b]{2}{*}{$31-31$} \\
\hline & \begin{tabular}{|l|} 
C17 Manufacture of paper and paper products \\
C18 Printing and reproduction of recorded media
\end{tabular} & & \\
\hline & C19 Manufacture of coke and refined petroleum products & & \\
\hline & C20 Manufacture of chemicals and chemical products & & \\
\hline 6.Chemicals & C21 Manufacture of basic pharmaceutical products and pharmaceutical preparations & ISIC 24-25 & 32,33 \\
\hline & C22 Manufacture of rubber and plastic products & & \\
\hline 12. Other manufactures & C23 Manufacture of other non-metallic mineral products & ISIC 23, 26 & $34,39,42$ \\
\hline & C24 Manufacture of basic metals & & \\
\hline 7.Metals & C25 Manufacture of fabricated metal products, except machinery and equipment & |ISIC 27-28 & $35,36,37$ \\
\hline & C26 Manufacture of computer, electronic and optical products & & \\
\hline 10.Electronics & C27 Manufacture of electrical equipment & JISIC 30, 32 & 40 \\
\hline 11.Other machinery & C28 Manufacture of machinery and equipment n.e.c. & ISIC 29, 31, 33 & 41 \\
\hline 8. Motor vehicles & C29 Manufacture of motor vehicles, trailers and semi-trailers & ISIC 34 & 38 \\
\hline 9. Other transport & C30 Manufacture of other transport equipment & ISIC 35 & 39 \\
\hline & C31 Manufacture of furniture & & \\
\hline 12.Other manufactures & C32 Other manufacturing & JISIC 23, 26 & $34,39,42$ \\
\hline 11.Other machinery & C33 Repair and installation of machinery and equipment & ISIC 29, 31, 33 & 41 \\
\hline & D Electricity, gas, steam and air conditioning supply & & \\
\hline & D35 Electricity, gas, steam and air conditioning supply & & \\
\hline & E Water supply; sewerage, waste management and remediation activities & & \\
\hline 21.Other services & E36 Water collection, treatment and supply & ISIC $40,41,50,51,52,63,75,80,85,90$ & $43,44,45,47$ \\
\hline & E37 Sewerage & & \\
\hline & E38 Waste collection, treatment and disposal activities; materials recovery & & \\
\hline & E39 Remediation activities and other waste management services & & \\
\hline & F Construction & & \\
\hline 13 Construction & F41 Construction of buildings & ISIC 45 & 46 \\
\hline 13.Construction & F42 Civil engineering & ISIC 45 & 46 \\
\hline & F43 Specialised construction activities & & \\
\hline & G Wholesale and retail trade; repair of motor vehicles and motorcycles & & \\
\hline & G45 Wholesale and retail trade and repair of motor vehicles and motorcycles & & \\
\hline 21.Other services & G454 Sale, maintenance and repair of motorcycles and related parts and accessories & ISIC $40,41,50,51,52,63,75,80,85,90$ & $43,44,45,47$ \\
\hline & G47 Retail trade, except of motor vehicles and motorcycles & & \\
\hline & H49 Land transport and transport via pipelines & & \\
\hline 14. Water Transport & H50 Water transport & ISIC 61 & 49 \\
\hline 15.Air Transport & H51 Air transport & ISIC 62 & 50 \\
\hline 21.Other services & H52 Warehousing and support activities for transportation & ISIC $40,41,50,51,52,63,75,80,85,90$ & $43,44,45,4748,56$ \\
\hline 16.Communications & H53 Postal and courier activities & ISIC $70-74$ & 51 \\
\hline O1 Other corvices & I55 Accommodation & ISIC $40,41,50,51,52,63,75,80,85,90$ & $43,44,45,47$ \\
\hline 21.Uther services & I56 Food and beverage service activities & ISIC $40,41,50,51,52,63,75,80,85,90$ & $48,56,57$ \\
\hline 19.Business services & J582 Software publishing & ISIC 91-93 & 54 \\
\hline & J59 Motion picture, video and television programme production, sound recording & & \\
\hline 20.Personal services & J60 Programming and broadcasting activities & ISIC 91-93 & 55 \\
\hline 16.Communications & J61 Telecommunications & ISIC 70-74 & 51 \\
\hline & J62 Computer programming, consultancy and related activities & & \\
\hline 19.Business services & \begin{tabular}{|l|l} 
J63 Information service activities \\
\end{tabular} & ISIC 91-93 & 54 \\
\hline 17.Finance & K64 Financial service activities, except insurance and pension funding & ISIC 65,67 & 52 \\
\hline 18.Insurance & K65 Insurance, reinsurance and pension funding, except compulsory social security & ISIC 66 & 53 \\
\hline 17.Finance & K66 Activities auxiliary to financial services and insurance activities & ISIC 65,67 & 52 \\
\hline & L68 Real estate activities & & \\
\hline & M69 Legal and accounting activities & & \\
\hline & M70 Activities of head offices; management consultancy activities & & \\
\hline & M71 Architectural and engineering activities; technical testing and analysis & & \\
\hline 10 Business services & M72 Scientific research and development & & \\
\hline 19.Busıness services & M73 Advertising and market research & ISIC 91-93 & 54 \\
\hline & M74 Other professional, scientific and technical activities & & \\
\hline & M75 Veterinary activities & & \\
\hline & N77 Rental and leasing activities & & \\
\hline & N78 Employment activities & & \\
\hline 21.Other services & N79 Travel agency, tour operator reservation service and related activities & ISIC $40,41,50,51,52,63,75,80,85,90$ & $43,44,45,4748,56$ \\
\hline & N80 Security and investigation activities & & \\
\hline 19.Business services & N81 Services to buildings and landscape activities & ISIC 91-93 & 54 \\
\hline & N82 Office administrative, office support and other business support activities & & \\
\hline & O - Public administration and defence; compulsory social security & & \\
\hline 21.Other services & P - Education & ISIC $40,41,50,51,52,63,75,80,85,90$ & $\begin{array}{l}43,44,45,47 \\
48,56,57\end{array}$ \\
\hline & Q - Human health and social work activities & & \\
\hline & $\mathrm{R}$ - Arts, entertainment and recreation & & \\
\hline & S - Other services activities & & \\
\hline 20.Personal services & S95 Repair of computers and personal and household goods & |ISIC 91-93 & 55 \\
\hline & T - Activities of households as employers; undifferentiated goods and services & & \\
\hline
\end{tabular}


Appendix 2. Mapping of model regions.

\begin{tabular}{|c|c|c|c|c|}
\hline $\begin{array}{l}\text { Latin America and the } \\
\text { Caribbean } \\
\text { (Latin America, LAC) }\end{array}$ & $\begin{array}{l}\text { Middle East, North Africa, } \\
\text { Afghanistan and Pakistan } \\
\text { (Middle-East, MEN) }\end{array}$ & $\begin{array}{l}\text { Sub-Saharan Africa } \\
\text { (Sub-Saharan A., SSA) }\end{array}$ & $\begin{array}{c}\text { Emerging and Developing Asia } \\
\text { (Southeast Asia, SEA) }\end{array}$ & $\begin{array}{l}\text { Other advanced countries } \\
\text { OAC }\end{array}$ \\
\hline Antigua and Barbuda & Afghanistan & Angola & Bangladesh & Hong Kong SAR \\
\hline Argentina & Algeria & Benin & Bhutan & Iceland \\
\hline The Bahamas & Armenia & Botswana & Brunei Darussalam & Israel \\
\hline Barbados & Azerbaijan & Burkina Faso & Cambodia & Korea \\
\hline Belize & Bahrain & Burundi & Fiji & New Zealand \\
\hline Bolivia & Belarus & Cameroon & Indonesia & Norway \\
\hline Brazil & Djibouti & Cabo Verde & Kiribati & Singapore \\
\hline Chile & Egypt & Central African Republic & Lao P.D.R. & San Marino \\
\hline Colombia & Georgia & Chad & Malaysia & Switzerland \\
\hline Costa Rica & Iran & Comoros & Maldives & Taiwan Province of China \\
\hline Dominica & Iraq & Dem. Rep. of the Congo & Marshall Islands & \\
\hline Dominican Republic & Jordan & Republic of Congo & Micronesia & \\
\hline Ecuador & Kazakhstan & Côte d'Ivoire & Mongolia & \\
\hline El Salvador & Kyrgyzstan & Equatorial Guinea & Myanmar & \\
\hline Grenada & Kuwait & Eritrea & Nepal & \\
\hline Guatemala & Lebanon & Ethiopia & Palau & \\
\hline Guyana & Libya & Gabon & Papua New Guinea & \\
\hline Haiti & Mauritania & The Gambia & Philippines & \\
\hline Honduras & Morocco & Ghana & Samoa & \\
\hline Jamaica & Oman & Guinea & Solomon Islands & \\
\hline Mexico & Pakistan & Guinea-Bissau & Sri Lanka & \\
\hline Nicaragua & Qatar & Kenya & Thailand & \\
\hline Panama & Russia & Lesotho & Timor-Leste & \\
\hline Paraguay & Rest of Eastern Europe & Liberia & Tonga & \\
\hline Peru & Rest of Former Soviet Union & Madagascar & Tuvalu & \\
\hline St. Kitts and Nevis & Saudi Arabia & Malawi & Vanuatu & \\
\hline St. Lucia & Sudan $^{1}$ & Mali & Vietnam & \\
\hline St.Vincent \& the Grenadines & Syria $^{2}$ & Mauritius & & \\
\hline Suriname & Tunisia & Mozambique & & \\
\hline Trinidad and Tobago & Turkey & Namibia & & \\
\hline Uruguay & Ukraine & Niger & & \\
\hline \multirow[t]{14}{*}{ Venezuela } & United Arab Emirates & Nigeria & & \\
\hline & Yemen & Rwanda & & \\
\hline & & São Tomé and Príncipe & & \\
\hline & & Senegal & & \\
\hline & & Seychelles & & \\
\hline & & Sierra Leone & & \\
\hline & & South Africa & & \\
\hline & & South Sudan & & \\
\hline & & Swaziland & & \\
\hline & & Tanzania & & \\
\hline & & Togo & & \\
\hline & & Uganda & & \\
\hline & & Zambia & & \\
\hline & & Zimbabwe & & \\
\hline
\end{tabular}

Note: the classification follows the one of the IMF World Economic Outlook. 